\title{
Water's path from moss to soil: A multi-methodological study on water absorption and evaporation of soil-moss combinations
}

\author{
Sonja M. Thielen ${ }^{1, \infty}$, Corinna Gall², ${ }^{2}$, Martin Ebner $^{3},{\text { Martin } \mathrm{Nebel}^{4} \text {, Thomas Scholten }}^{2}$, Steffen Seitz ${ }^{2, *}$ \\ ${ }^{1}$ Invertebrate Palaeontology and Palaeoclimatology, Department of Geosciences, University of Tübingen, Schnarrenbergstr. 94-96, 72076 \\ Tübingen, Germany. \\ ${ }^{2}$ Soil Science and Geomorphology, Department of Geosciences, University of Tübingen, Rümelinstr. 19-23, 72070 Tübingen, Germany. \\ ${ }^{3}$ Biogeology, Department of Geosciences, University of Tübingen, Hölderlinstr. 12, 72074 Tübingen, Germany. \\ ${ }^{4}$ Nees-Institute for Biodiversity of Plants, University of Bonn, Meckenheimer Allee 170, 53115 Bonn, Germany. \\ * Corresponding author. Tel.: +49 (0)7071-29-77523. E-mail: steffen.seitz@uni-tuebingen.de \\ ${ }^{\infty}$ These authors contributed equally to this project and are considered co-first authors.
}

\begin{abstract}
Mosses are often overlooked; however, they are important for soil-atmosphere interfaces with regard to water exchange. This study investigated the influence of moss structural traits on maximum water storage capacities (WSC $\mathrm{max}_{\max }$ and evaporation rates, and species-specific effects on water absorption and evaporation patterns in moss layers, mosssoil-interfaces and soil substrates using biocrust wetness probes. Five moss species typical for Central European temperate forests were selected: field-collected Brachythecium rutabulum, Eurhynchium striatum, Oxyrrhynchium hians and Plagiomnium undulatum; and laboratory-cultivated Amblystegium serpens and Oxyrrhynchium hians.

WSC $_{\text {max }}$ ranged from $14.10 \mathrm{~g} \mathrm{~g}^{-1}$ for Amblystegium serpens (Lab) to $7.31 \mathrm{~g} \mathrm{~g}^{-1}$ for Plagiomnium undulatum when immersed in water, and $11.04 \mathrm{~g} \mathrm{~g}^{-1}$ for Oxyrrhynchium hians (Lab) to $7.90 \mathrm{~g} \mathrm{~g}^{-1}$ for Oxyrrhynchium hians when sprayed, due to different morphologies depending on the growing location. Structural traits such as high leaf frequencies and small leaf areas increased $\mathrm{WSC}_{\max }$. In terms of evaporation, leaf frequency displayed a positive correlation with evaporation, while leaf area index showed a negative correlation. Moisture alterations during watering and desiccation were largely controlled by species/substrate-specific patterns. Generally, moss cover prevented desiccation of soil surfaces and was not a barrier to infiltration. To understand water's path from moss to soil, this study made a first contribution.
\end{abstract}

Keywords: Biological soil crusts; Bryophytes; Ecohydrology; Moss structure; Moss hydrology; Rainfall interception.

\section{INTRODUCTION}

Bryophytes occur in a wide range of ecosystems, from arctic and boreal enviroments to temperate and tropical forests, drylands, and even deserts (Hedenäs, 2007; Lindo and Gonzalez, 2010; Medina et al., 2011). They often form community assemblages with other organisms such as lichens, fungi, algae, cyanobacteria and bacteria, which form what are termed biological soil crusts (biocrusts) (Belnap et al., 2016). With approximately 20000 species, they are the second biggest group of land plants, comprising mosses, liverworts and hornworts (Frey et al., 2009; Söderström et al., 2016). Moss layers fulfill crucial functional roles in a variety of ecosystems regarding water and nutrient fluxes (Bond-Lamberty et al., 2011; Cornelissen et al., 2007; Gundule et al., 2011) as well as soil physical properties (Soudzilovskaia et al., 2013). In contrast to vascular plants, mosses do not actively regulate their water content, but are poikilohydric, meaning their internal water content is in equilibrium with ambient humidity (Green and Lange, 1994). For mosses, water is primarily available via rain, dew and fog (Glime, 2017) and moss moisture is influenced by many factors, depending on the habitat as well as the species itself in regard to structure and life form (Dilks and Proctor, 1979; Oishi, 2018; Proctor, 1982; Proctor, 2000; Proctor and Tuba, 2002 ), i.e. the form of individual moss shoots growing together, which is considered an ecologically functional unit (Bates, 1998; Mägdefrau, 1982).

Water absorption occurs mainly via the external capillaries (ectohydric), but in some species also via internal (endohydric) movement. While the latter is achieved cell by cell or through special water conducting cells (hydroids), the ectohydric movement of water is through spaces between adjacent shoots, leaves, leaves and stems, leaves and rhizoids and capillary systems such as leaf bases, revoluted leaf margins, grooves or networks of capillary channels determined by papillae (Giordano et al., 1993; Glime, 2017). According to Schofield (1981), capillary spaces are influenced by numerous structural parameters such as leaf shape, leaf arrangement, leaf orientation, detailed leaf anatomy (e.g. surface ornamentation), branch arrangement, nature of cortical cells, and presence of rhizoids or paraphyllia. Nevertheless, there is still limited data on moss structural traits and water relations (Elumeeva et al., 2011). Overall, mosses achieve maximum water storage capacities of $108 \%$ to $2070 \%$ of their dry weight (Proctor et al., 1998), with some Sphagnum species even reaching over $5000 \%$ of dry weight (Wang and Bader, 2018).

Many mosses are capable of drying out without dying, which means they can endure losing all free intracellular water and recover their ordinary functions afterwards, such as photosynthesizing and growing when water is available (Proctor et al., 2007). Due to their high surface to volume ratios, rapid drying is generally facilitated (Proctor et al., 2007). Typically, moss cells are either completely turgid or desiccated, with relatively short transitions in between (Proctor et al., 2007). Factors influencing this water loss by evaporation are microclimatic conditions (Proctor, 1990), life form characteristics (Elumeeva et al., 2011; Mägdefrau and Wutz, 1951; Nakatsubo, 1994; Zotz et al., 1997) and canopy structural properties such as surface roughness, shoot density and cushion height (Goetz and Price, 2015; Rice and Schneider, 2004; Rice et al., 2001, 2018). 
As an example of cushion life forms, Zotz et al. (2000) and Rice and Schneider (2004) found that evaporation rates decrease with moss cushion size.

For water balance of forest ecosystems, an intact forest floor cover such as leaf litter covers or moss layers play a crucial role (Acharya et al., 2017; Gerrits and Savenije, 2011; Mägdefrau and Wutz, 1951; Sayer, 2006). In mid- and high-latitude coniferous forests, moss layers often form at ground level (Elbert et al., 2012). As forest ecosystems have suffered from drought in recent years (Senf et al., 2020) and mosses are also increasingly threatened by global warming (He et al., 2016), it is particularly important to investigate their hydrological effects in these environments. Previous research by Price et al. (1997) in Canadian boreal forests showed that moss layers could retain $16.8 \mathrm{~mm}$ of water, which was approximately $21 \%$ of the precipitation input. Furthermore, Carleton and Dunham (2003) found that mosses in a boreal forest could not be fully hydrated by capillary water movement from the forest floor or dewfall, but rather from vapour from the forest floor condensing on the moss surface. Liu and She (2020) investigated a linear decrease of soil evaporation with increasing moss biomass, using moss that was previously cultivated in the laboratory. Overall, the forest floor water balance is influenced by the amounts of throughfall rain, the processes in the moss carpet, and the processes at the mosssoil interface (Price et al., 1997). However, little is known about how much water mosses release into the atmosphere and how much is transported from the soil to the moss and vice versa (Glime, 2017; Voortman et al., 2014). In particular, the influence of different moss species on water movement through moss layers into the soil has been largely disregarded in this context, but has in turn shown great effects on e.g. erosion control (Seitz et al., 2017).

With this study, we aim to shorten this knowledge gap in an interdisciplinary approach (cf. Liu and She (2020)). To do so, we examined water absorption and evaporation patterns in moss-covered soil substrates typical for a Central European temperate forest during and after watering. We hypothesize that:

1. Maximum water storage capacities $\left(\mathrm{WSC}_{\max }\right.$ ) of mosses are species-specific and positively affected by their surface area.

2. Differences in the temporal dynamics of water content during watering and subsequent desiccation depend largely on the combination of moss species and the underlying soil substrates.

To test our hypotheses, we set up a greenhouse experiment with five moss species and four soil substrates, whereby artificially cultivated mosses of the same species were also included. We used biocrust wetness probes (Weber et al., 2016) for high-resolution monitoring of water content in moss layers, on the soil surface, and in a soil depth of $3 \mathrm{~cm}$. Furthermore, we investigated the selected mosses in terms of their structural traits and their maximum water storage capacities.

\section{METHODS}

\section{Moss and soil characteristics}

Five moss species native to Southwest Germany (Nebel et al., 2001) differing in origin, classification and growth form were chosen for the study (Table 1). Oxyrrhynchium hians (Hedw.) Loeske, Eurhynchium striatum (Hedw.) Schimp., Plagiomnium undulatum (Hedw.) T.J.Kop. and Brachythecium rutabulum (Hedw.) Schimp. were collected in the field at different sites within the Ammer and Neckar valley. Cultures of Amblystegium serpens (Hedw.) Schimp. and Oxyrrhynchium hians were grown in a hydraulic fluid in an in vitro environment by Hummel InVitro GmbH in Stuttgart, Germany. The latter was selected a second time to study intraspecific differences between field and cultivated mosses. With regard to the position of the sporophytes, all selected mosses were pleurocarpous (side-fruited), except $P$. undulatum, which was acrocarpous (top-fruited).

Soil substrates were chosen according to common growing conditions of selected moss species and sampled from four different sites in the Schönbuch Nature Park in Southwest Germany. Sampling sites were located in the geological series of the Lower Jurassic, with shale clay, interstratified by beds of pyrite and fine grained sandstone, as well as in the Upper Triassic, where claystone with fine lime nodules and fine to coarse grained sandstone is present (Einsele and Agster, 1986). The substrates varied with regard to parent material, soil texture, and $\mathrm{pH}$ as well as the $\mathrm{C} / \mathrm{N}$ ratio (Table 2). They were sampled from the topsoil to a depth of $10 \mathrm{~cm}$ and sieved by $6.3 \mathrm{~mm}$. Below, we distinguish the substrates according to their geological formation: Angulatensandstein (AS), Psilonotenton (PT), Löwenstein (LS) and Trossingen (TS) (Einsele and Agster, 1986).

\section{Greenhouse experiment}

With a greenhouse experiment, we investigated water absorption patterns in moss covers and corresponding soil substrates during and after watering. To do this, we filled the substrates into infiltration boxes $(40 \mathrm{~cm} \times 30 \mathrm{~cm} \times 15 \mathrm{~cm})$ up to a height of $6.5 \mathrm{~cm}$. Infiltration boxes are stainless steel containers with a triangular surface runoff gutter and an outlet on the bottom to capture percolated water. In December 2019, moss species were placed onto substrate-filled infiltration boxes, leading to 6 treatments with 2 replicates each: $P$. undulatum (Field) + PT, O. hians (Field) + AS, $O$. hians (Lab) + AS, $B$. rutabulum $($ Field $)+$ LS, A. serpens $(\mathrm{Lab})+\mathrm{LS}$, E. striatum + TS; yielding a total number of 12 boxes. Infiltration boxes were subsequently stored in a shady place outdoors for adaptation, until we began the greenhouse experiment in July 2020.

Table 1. Characteristics of studied moss samples.

\begin{tabular}{|c|c|c|c|c|c|c|}
\hline & $\begin{array}{l}\text { Amblystegium } \\
\text { serpens }\end{array}$ & $\begin{array}{l}\text { Brachythecium } \\
\text { rutabulum }\end{array}$ & $\begin{array}{l}\text { Eurhynchium } \\
\text { striatum }\end{array}$ & $\begin{array}{l}\text { Oxyrrhynchium } \\
\text { hians }\end{array}$ & $\begin{array}{l}\text { Oxyrrhynchium } \\
\text { hians }\end{array}$ & $\begin{array}{l}\text { Plagiomnium } \\
\text { undulatum }\end{array}$ \\
\hline Family & Amblystegiaceae & Brachytheciaceae & Brachytheciaceae & Brachytheciaceae & Brachytheciaceae & Mniaceae \\
\hline Origin & Lab & Field & Field & Field & Lab & Field \\
\hline $\begin{array}{l}\text { Site } \\
\text { characteristics }\end{array}$ & - & $\begin{array}{l}\text { ruderalized fertile } \\
\text { meadow }\end{array}$ & pinewood & $\begin{array}{l}\text { dry hedge } \\
\text { understore }\end{array}$ & - & flood plain \\
\hline Growth form & pleurocarpous & pleurocarpous & pleurocarpous & pleurocarpous & pleurocarpous & acrocarpous \\
\hline $\begin{array}{l}\text { Sample site } \\
\text { coordinates }\end{array}$ & - & $\begin{array}{l}\text { Tübingen } \\
48.544917 \mathrm{~N} \\
9.043309 \mathrm{E}\end{array}$ & $\begin{array}{l}\text { Tübingen } \\
48.546194 \mathrm{~N} \\
9.036407 \mathrm{E}\end{array}$ & $\begin{array}{l}\text { Reusten } \\
48.541665 \mathrm{~N} \\
8.914316 \mathrm{E}\end{array}$ & - & $\begin{array}{l}\text { Pliezhausen } \\
48.566723 \mathrm{~N} \\
9.216494 \mathrm{E}\end{array}$ \\
\hline
\end{tabular}


Water's path from moss to soil: A multi-methodological study on water absorption and evaporation of soil-moss combinations

Table 2. Characteristics of studied soil substrates.

\begin{tabular}{|c|c|c|c|c|}
\hline & $\mathrm{AS}$ & PT & LS & TS \\
\hline Series & Lower Jurassic & Lower Jurassic & Upper Triassic & Upper Triassic \\
\hline Formation & $\begin{array}{l}\text { Angulatensandstein- } \\
\text { Formation (AS) }\end{array}$ & $\begin{array}{l}\text { Psilonotenton-Formation } \\
\text { (PT) }\end{array}$ & $\begin{array}{l}\text { Löwenstein-Formation } \\
\text { (LS) }\end{array}$ & $\begin{array}{l}\text { Trossingen-Formation } \\
\text { (TS) }\end{array}$ \\
\hline Parent material & sandstone & shale clay & sandstone & claystone \\
\hline Soil texture & $\begin{array}{l}\text { silt loam } \\
\text { - sand: } 7.00 \% \\
\text { - silt: } 67.58 \% \\
\text { - clay: } 25.68 \% \\
\end{array}$ & $\begin{array}{l}\text { silty clay loam } \\
\text { - sand: } 6.88 \% \\
\text { - silt: } 56.28 \% \\
\text { - clay: } 36.93 \% \\
\end{array}$ & $\begin{array}{l}\text { clay loam } \\
\text { - sand: } 25.02 \% \\
\text { - silt: } 42.43 \% \\
\text { - clay: } 32.60 \\
\end{array}$ & $\begin{array}{l}\text { silty clay loam } \\
\text { - sand: } 10.78 \% \\
\text { - silt: } 50.83 \% \\
\text { - clay: } 38.10 \% \\
\end{array}$ \\
\hline $\mathrm{C} / \mathrm{N}$ & 17.54 & 17.36 & 23.12 & 20.05 \\
\hline $\mathrm{pH}$ & 5.8 & 7.0 & 7.0 & 5.6 \\
\hline $\begin{array}{l}\text { Sample site } \\
\text { coordinates }\end{array}$ & $\begin{array}{l}\text { Tübingen } \\
48.553054 \mathrm{~N} \\
9.119053 \mathrm{E} \\
\end{array}$ & $\begin{array}{l}\text { Tübingen } \\
48.557425 \mathrm{~N} \\
9.114462 \mathrm{E} \\
\end{array}$ & $\begin{array}{l}\text { Tübingen } \\
48.557527 \mathrm{~N} \\
9.088098 \mathrm{E} \\
\end{array}$ & $\begin{array}{l}\text { Tübingen } \\
48.556036 \mathrm{~N} \\
9.089313 \\
\end{array}$ \\
\hline
\end{tabular}

To measure water content (WC), we installed three biocrust wetness probes (BWP; UP GmbH, Cottbus, Germany) per infiltration box in different positions: in $3 \mathrm{~cm}$ soil depth, in the uppermost $5 \mathrm{~mm}$ of the soil surface and in the moss layer (Fig. 1). BWPs were specifically developed to quantify WC of soil surfaces as well as biocrusts by deriving WC from electrical conductivity measurements; they provided reliable data in several experiments under different field conditions (Gypser et al., 2017; Löbs et al., 2020; Tucker et al., 2017; Weber et al., 2016). Samples were irrigated for one hour with a sprayer (Comfort Sensitive Plant, Gardena, Ulm, Germany) with $6 \mathrm{~L} \mathrm{~h}^{-1}$ of water, split into $500 \mathrm{~mL}$ every $5 \mathrm{~min}$, corresponding to a precipitation amount of $122 \mathrm{~mm}$ (extremely heavy rainfall event). All BWPs were installed underneath the centre of the sprayer, whereby we ensured that the BWP in the moss layer was completely encased by moss shoots. During this watering and subsequent desiccation process in the greenhouse, the electrical conductivity of the samples was logged every 10 seconds for 72 hours with the BWPs connected to a GP2 Data Logger (Delta-T Devices, Cambridge, UK). Additionally, air temperature and relative humidity $(\mathrm{RH})$ in the greenhouse were monitored (Tinytag Plus 2 - TGP-4500, Gemini Data Loggers, Chichester, UK) for the same time slots. Soil WC was determined before and after watering as well as after 71 hours of desiccation applying two methods: first, we substrate inside
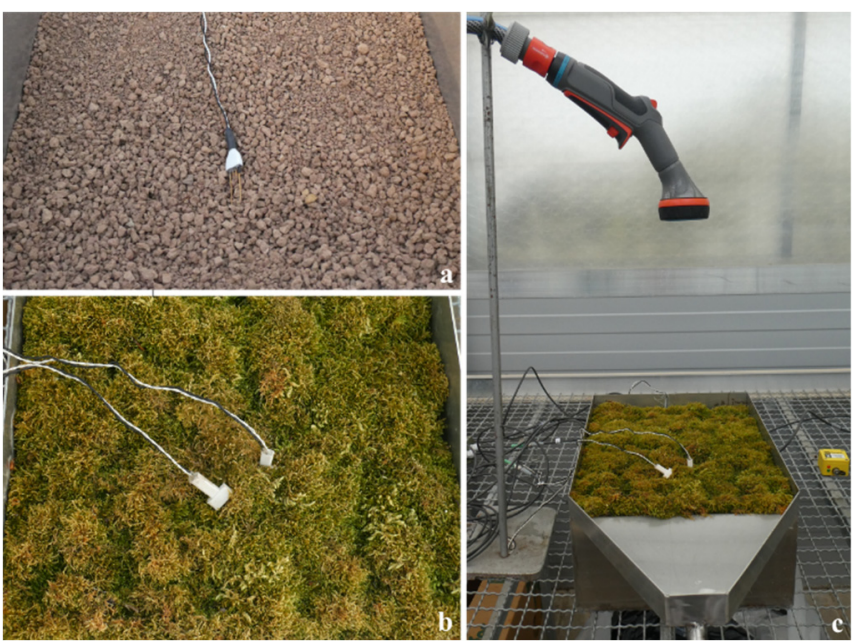

Fig. 1. Overview of the greenhouse experiment setup. a) Biocrust wetness probe (BWP) in $3 \mathrm{~cm}$ soil depth, b) BWP in soil surface and moss cover, c) experimental setup with moss-covered soil the infiltration box and sprayer installed at uniform height. used a gravimetrical approach with a heavy-duty precision balance (KERN FCB 30K1, Kern \& Sohn GmbH, Balingen, Germany), and second, we used a Thetaprobe ML2 in combination with a HH2 Moisture Meter (Delta-T Devices, Cambridge, UK).

To consider evaporation effects during the period of desiccation, we calculated the evaporation rate of this time span for all samples using the formula

$E=\frac{W C_{0}-W C_{x}}{t_{x}-t_{0}}$,

where $W C_{0}$ is the maximum gravimetric $\mathrm{WC}$ in the examined time period, $W C_{x}$ is the gravimetric $\mathrm{WC}$ at time point $\mathrm{x}$, and $\mathrm{t}_{\mathrm{x}}$ and $t_{0}$ are the respective time points (Robinson et al., 2000).

\section{Laboratory BWP calibration}

To calibrate the BWP to gravimetric WC, we monitored weight loss and electrical conductivity (EC) simultaneously for all samples under laboratory conditions for at least 65 hours (average air temperature: $19.1{ }^{\circ} \mathrm{C}, \mathrm{sd}=1.2{ }^{\circ} \mathrm{C}$; average relative humidity $(\mathrm{RH}): 45.8 \%$, sd $=5.9 \%$ ). Samples were water saturated using the immersion technique described below (in the following section). Afterwards, they were placed on a balance (Kern EW 620-3NM, Kern \& Sohn GmbH, Balingen, Germany) and three BWPs were installed in each sample. Two samples were measured in parallel, using two precision balances of the same type. BWP and weight data were recorded at an interval of 10 seconds, while temperature and relative humidity were logged in 5 min intervals with Tinytag Plus 2 (see above).

During monitoring of weight loss, the scales generated individual error values, which required a filtering of data. Since the scales only measured stable values, we had irregular time intervals in the recording of weight losses. To be able to combine weight and BWP as well as RH and temperature values, we performed a linear fashion interpolation with both weight values and climate measurements.

As EC is affected by temperature, we conducted a temperature correction and derived the WC for a specific value of the BWP as described in Weber et al. (2016). According to Slatyer (1967), the formula

$W C=\frac{(W W-D W)}{D W}$

was used, where $W C$ is the gravimetric $W C\left(\mathrm{~g} \mathrm{~g}^{-1}\right), W W$ is the wet weight $(\mathrm{g})$ and $D W$ is the dry weight $(\mathrm{g})$ of the soil or moss sample. 
The last step of calibration included curve fitting, where we used the mean of the three BWP values and the calculated WC. We found linear relationships which can be characterized as $\mathrm{WC}=\mathrm{a} \cdot \mathrm{EC}_{\mathrm{t}}+\mathrm{b}$. For non-linear relationships we used nonlinear least-square regressions expressed by the equation $\mathrm{WC}=\exp \left(\mathrm{a} \cdot \mathrm{EC}_{\mathrm{t}}\right) \cdot \mathrm{b} \cdot \mathrm{EC}_{\mathrm{t}}+\mathrm{c}$, as recommended in Weber et al. (2016). Furthermore, some relationships could be better described with the equation $\mathrm{WC}=\exp \left(\mathrm{a}+\mathrm{b} \cdot \mathrm{EC}_{\mathrm{t}}\right)$. While the moss samples could be dried from saturation to desiccation, soil samples did not dry out completely during the laboratory calibration. Therefore, an extrapolation of data for the calibration BWP values was necessary for the soil samples. An overview of all calibration curves is shown in Table S1 in the supporting information.

\section{Maximum water storage capacity}

For a detailed characterisation of moss species and adjunct soil substrates with regard to their maximum water storage capacity $\left(\mathrm{WSC}_{\max }\right)$, further laboratory experiments were conducted with samples from the infiltration boxes. Therefore, we detached the mosses from the soil, dried them at $30{ }^{\circ} \mathrm{C}$ in a dehydrator (Dörrex 0075.70, Stöckli, Netstal, Switzerland) and weighed the dry samples (Mettler Toledo MS603S, Mettler Toledo, Columbus, USA). Soil samples were taken with $100 \mathrm{~cm}^{3}$ metal core cutters from every infiltration box, dried at $105{ }^{\circ} \mathrm{C}$ in a compartment drier and weighed in dry state. Afterwards both moss species and soil substrates were saturated, using two different methods for the mosses: spray and immersion technique. For the spray technique, we moistened the mosses that had been placed in a petri plate with a spray bottle from above until samples could no longer absorb water. The excess water was removed with a pipette and volume was determined with a $25 \mathrm{~mL}$ measuring cylinder. By weighing the spray bottle before and after spraying we estimated the amount of water added to the mosses (in average $3.45 \mathrm{~mm}$ ). The wet mosses were weighed again with the same balance. In contrast, with the immersion technique we moistened the mosses by submerging them in water for $5 \mathrm{~min}$ between two soil sieves with $52 \mu \mathrm{m}$ mesh size on the bottom and $250 \mu \mathrm{m}$ on the top, then drained them for $2 \mathrm{~min}$, and then weighed them. We decided to use these two approaches, as we observed that some mosses were still dry on the bottom after a rainfall event, which was also described in Glime (2017). Therefore, we expected different mechanisms of water absorption in the two techniques, with the spray technique probably being more similar to the greenhouse watering process. The soil samples were placed into a tub of water until the surface was wet and afterwards we measured the wet weight. To ensure that the soil substrate remained in the core cutter during rewetting, we attached a thin water permeable fleece to the bottom of the core cutter (Blume et al., 2011).

\section{Moss structural trait measurements}

To determine the surface areas of the studied moss species, we measured the following structural traits: leaf area, leaf frequency, shoot length, length of a single component (sum of shoot length and length of attached branches), shoot density (Table 3). We determined the surface areas of the studied species using the following formula, which we adapted for our experiment following Simon (1987), Niinemets and Tobias (2014) and Niinemets and Tobias (2019):

$A_{\text {bryo }}=L N_{\text {shoot }} \frac{A_{\text {leaf }}}{1 \mathrm{~cm} \text { shoot }}$

where Abryo is moss surface area, $L$ is the average length of a shoot with its attached branches, $N_{\text {shoot }}$ is mean number of measured shoots, and $A_{\text {leaf }}$ is mean leaf area. Leaf area index (LAI) was then calculated with the formula

$$
L A I=\frac{A_{\text {bryo }}}{\text { sample area }}
$$

In the first step, three circular samples with a diameter of 5.5 $\mathrm{cm}$ (sample area) were taken from each species. Moss samples were then dissembled into single moss shoots. Due to the very dense structure and consequent long time duration, only half of the circular area of $A$. serpens was considered. Next, detached shoots were scanned using a high definition flatbed scanner

Table 3. Species-specific average values ( \pm standard error of the mean) of leaf area, leaf frequency, leaf area per shoot length, shoot length, length of a single component (sum of shoot length and length of attached branches), shoot density (shoot number per ground area), total surface area, leaf area index (LAI), moss cushion height, volume and density for the studied moss species.

\begin{tabular}{|c|c|c|c|c|c|c|c|c|c|c|c|}
\hline Species & $\begin{array}{l}\text { Leaf } \\
\text { area } \\
\left(\mathrm{mm}^{2}\right)\end{array}$ & $\begin{array}{l}\text { Leaf fre- } \\
\text { quency } \\
\left(\mathrm{cm}^{-1}\right)\end{array}$ & $\begin{array}{l}\text { Leaf area } \\
\text { per shoot } \\
\text { length } \\
\left(\mathrm{cm}^{2} \mathrm{~cm}^{-1}\right)\end{array}$ & $\begin{array}{l}\text { Shoot } \\
\text { length } \\
(\mathrm{cm})\end{array}$ & $\begin{array}{l}\text { Length single } \\
\text { component } \\
(\mathrm{cm})\end{array}$ & $\begin{array}{l}\text { Shoot } \\
\text { density } \\
\left(\mathrm{n} \mathrm{cm}^{-2}\right)\end{array}$ & $\begin{array}{l}\text { Total } \\
\text { surface } \\
\text { area }\left(\mathrm{cm}^{2}\right)\end{array}$ & LAI & $\begin{array}{l}\text { Cushion } \\
\text { height } \\
(\mathrm{cm})\end{array}$ & $\begin{array}{l}\text { Cushion } \\
\text { volume } \\
\left(\mathrm{cm}^{3}\right)\end{array}$ & $\begin{array}{l}\text { Cushion } \\
\text { density } \\
\left(\mathrm{g} \mathrm{cm}^{-3}\right)\end{array}$ \\
\hline $\begin{array}{l}\text { Amblystegium } \\
\text { serpens (Lab) }\end{array}$ & $\begin{array}{l}0.104 \pm \\
0.002\end{array}$ & $\begin{array}{l}81.778 \pm \\
3.929\end{array}$ & $\begin{array}{l}0.085 \pm \\
0.006\end{array}$ & $\begin{array}{l}1.168 \pm \\
0.024\end{array}$ & $\begin{array}{l}1.764 \pm \\
0.224\end{array}$ & $\begin{array}{l}97.005 \pm \\
11.786\end{array}$ & 346.204 & 14.572 & $\begin{array}{l}1.322 \pm \\
0.091\end{array}$ & $\begin{array}{l}107.058 \pm \\
10.623\end{array}$ & $\begin{array}{l}0.026 \pm \\
0.002\end{array}$ \\
\hline $\begin{array}{l}\text { Brachythecium } \\
\text { rutabulum }\end{array}$ & $\begin{array}{l}1.151 \pm \\
0.035\end{array}$ & $\begin{array}{l}39.333 \pm \\
4.93\end{array}$ & $\begin{array}{l}0.452 \pm \\
0.064\end{array}$ & $\begin{array}{l}3.791 \pm \\
0.166\end{array}$ & $\begin{array}{l}8.470 \pm \\
0.286\end{array}$ & $\begin{array}{l}3.031 \pm \\
0.402\end{array}$ & 297.076 & 12.504 & $\begin{array}{l}1.536 \pm \\
0.116\end{array}$ & $\begin{array}{l}139.856 \pm \\
19.366\end{array}$ & $\begin{array}{l}0.018 \pm \\
0.001\end{array}$ \\
\hline $\begin{array}{l}\text { Eurhynchium } \\
\text { striatum }\end{array}$ & $\begin{array}{l}0.629 \pm \\
0.013\end{array}$ & $\begin{array}{l}91.333 \pm \\
9.541\end{array}$ & $\begin{array}{l}0.574 \pm \\
0.06\end{array}$ & $\begin{array}{l}2.018 \pm \\
0.129\end{array}$ & $\begin{array}{l}7.756 \pm \\
0.656\end{array}$ & $\begin{array}{l}2.511 \pm \\
0.496\end{array}$ & 265.672 & 11.182 & $\begin{array}{l}2.119 \pm \\
0.092\end{array}$ & $\begin{array}{l}182.071 \pm \\
18.683\end{array}$ & $\begin{array}{l}0.016 \pm \\
0.002\end{array}$ \\
\hline $\begin{array}{l}\text { Oxyrrhynchium } \\
\text { hians }\end{array}$ & $\begin{array}{l}0.307 \pm \\
0.006\end{array}$ & $\begin{array}{l}69.889 \pm \\
3.545\end{array}$ & $\begin{array}{l}0.187 \pm \\
0.008\end{array}$ & $\begin{array}{l}2.524 \pm \\
0.129\end{array}$ & $\begin{array}{l}8.124 \pm \\
0.702\end{array}$ & $\begin{array}{l}4.714 \pm \\
0.712\end{array}$ & 169.907 & 7.151 & $\begin{array}{l}1.65 \pm \\
0.13\end{array}$ & $\begin{array}{l}132.174 \pm \\
15.278\end{array}$ & $\begin{array}{l}0.015 \pm \\
0.002\end{array}$ \\
\hline $\begin{array}{l}\text { Oxyrrhynchium } \\
\text { hians (Lab) }\end{array}$ & $\begin{array}{l}0.393 \pm \\
0.008\end{array}$ & $\begin{array}{l}55.556 \pm \\
2.911\end{array}$ & $\begin{array}{l}0.219 \pm \\
0.014\end{array}$ & $\begin{array}{l}2.180 \pm \\
0.092\end{array}$ & $\begin{array}{l}6.198 \pm \\
1.480\end{array}$ & $\begin{array}{l}10.368 \pm \\
2.509\end{array}$ & 333.764 & 14.048 & $\begin{array}{l}1.353 \pm \\
0.136\end{array}$ & $\begin{array}{l}114.336 \pm \\
18.998\end{array}$ & $\begin{array}{l}0.022 \pm \\
0.003\end{array}$ \\
\hline $\begin{array}{l}\text { Plagiomnium } \\
\text { undulatum }\end{array}$ & $\begin{array}{l}4.737 \pm \\
0.129\end{array}$ & $\begin{array}{l}20.111 \pm \\
2.6\end{array}$ & $\begin{array}{l}0.953 \pm \\
0.121\end{array}$ & $\begin{array}{l}3.004 \pm \\
0.129\end{array}$ & $\begin{array}{l}4.960 \pm \\
0.571\end{array}$ & $\begin{array}{l}3.087 \pm \\
0.827\end{array}$ & 346.517 & 14.585 & $\begin{array}{l}1.394 \pm \\
0.08\end{array}$ & $\begin{array}{l}100.778 \pm \\
6.649\end{array}$ & $\begin{array}{l}0.018 \pm \\
0.001\end{array}$ \\
\hline
\end{tabular}


(Epson Perfection V700 Photo, Suwa, Japan) and shoot numbers of all samples were counted to determine the shoot number per unit sample area. Afterwards, if sample size enabled it, 50 shoots were randomly chosen for length measurements, using ImageJ versions 1.53e and Fiji 2.1.0 (Schindelin et al., 2012; Schneider et al., 2012). Next to shoot length, we also determined the length of branches that were attached to the measured shoots. Then, from each sample three shoots were randomly selected and all leaves were carefully removed along one centimeter of the shoot. The removed leaves were put on slides and were either scanned with the flatbed scanner or a digital microscope (Keyence VHX-7000 with dual zoom lens VH-ZST, Keyence, Osaka, Japan). Leaf area was subsequently measured with ImageJ as well.

Additionally, we determined the volume of the moss cushions for all moss samples used in the $\mathrm{WSC}_{\max }$ experiment. Therefore, we photographed all moss samples using a Nikon D5100 (Chiyoda, Japan), equipped with an AF-S DX Micro NIKKOR $40 \mathrm{~mm} \mathrm{f} / 2.8 \mathrm{G}$ lens to identify the individual sample area with ImageJ. The height of the moss cushions was measured at four sites with a calliper and mean values were calculated for every cushion. The moss cushion density was derived from the quotient of dry weight and cushion volume.

\section{Data analysis}

All analyses were conducted with R software versions 3.6.3 and 4.0.2 (R Core Team, 2021) on the level of individual samples. To examine significant differences, we used one-way ANOVAs in combination with post-hoc Tukey's HSD tests when variables showed homogeneity of variances. In other cases, we performed post-hoc Games-Howell or Wilcoxon signed-rank tests. Previously, homoescedasticity was verified with the Levene's test. To test for differences of the means between two samples we used Welch's t-test. Significance was assessed at $\mathrm{p}<0.05$ in all cases.

Furthermore, we performed pairwise Pearson as well as Spearman's Rank correlation analyses to screen for relationships between WSC $_{\max }$ as well as evaporation rates of the studied samples and parameters of sample characteristics. In advance of all analyses, we used the Shapiro-Wilk Test to examine the samples for normal distribution. Additionally, generalized additive models (GAM) with restricted maximum likelihood and smoothing parameters selected by an unbiased risk estimator (UBRE) criterion were performed to assess the effect of soil substrate or moss species characteristics on $\mathrm{WSC}_{\max }$. Firstly, we fitted moss WSC $_{\max }$ from the spray and immersion techniques against mean shoot number, mean leaf surface area, LAI, moss cushion height as well as moss cushion density. Secondly, $\mathrm{WSC}_{\max }$ of soil substrates were fitted against soil bulk density, sand, silt and clay contents as well as total carbon and nitrogen content.

\section{RESULTS AND DISCUSSION}

In order to discuss and answer the hypotheses presented, we first analyzed the differences in structural traits of the studied moss species and investigated their relationship with $\mathrm{WSC}_{\max }$. As we assumed that the temporal progression of $\mathrm{WC}$ in the greenhouse experiment could be explained by the structural traits of moss species, we further examined whether our samples showed similar patterns of properties in the different experiments.

\section{Moss structural traits}

A wide range of structural trait characteristics for the moss species used in this study were determined to explain moss water relations (Table 3). The average individual leaf area of the studied species ranged almost fivefold from $0.104 \mathrm{~mm}^{2}$ in A. serpens (Lab) to $4.737 \mathrm{~mm}^{2}$ in P. undulatum. Accordingly, average leaf area per shoot length varied elevenfold between $0.085 \mathrm{~cm}^{2} \mathrm{~cm}^{-1}$ in $A$. serpens (Lab) to 0.953 in $P$. undulatum. Leaf frequency was the smallest in $P$. undulatum at 20.111 and ranged up to 91.333 in E. striatum. We found the longest shoots in B. rutabulum ( $3.79 \mathrm{~cm}$ on average) and the shortest shoots in A. serpens (Lab) $(1.16 \mathrm{~cm}$ on average). After adding the length of attached branches to the respective shoot length, B. rutabulum still had the longest shoots with $8.47 \mathrm{~cm}$, and $A$. serpens (Lab) had the shortest shoots with $1.764 \mathrm{~cm}$. However, A. serpens (Lab) had the highest shoot density ( 97 shoots per $\mathrm{cm}^{2}$ ), whereas $B$. rutabulum, E. striatum, $O$. hians and $P$. undulatum had much lower densities between 2.5 to 4.714 shoots per $\mathrm{cm}^{2}$. Interestingly, shoot density of $O$. hians (Lab) was twice as high as for $O$. hians collected in nature, which might be due to missing competition with other species in a laboratory setting, as well as different light and water regimes, since moss structure is highly affected by water and light availability (Mägdefrau, 1982). This raises the question of whether field-collected $A$. serpens also has similarly high shoot densities as determined for $A$. serpens (Lab) in this study. While $A$. serpens (Lab) grew in dense and more voluminous lawns, A. serpens occurs more often intermingled with other species in nature. The nutrientloving species prefers semi-shady, rather moist sites that are also preferred by many other species that are often more vigorous and thus overgrow the delicate prostrate A. serpens (Nebel, 2001). The dense, extensive tall lawns of $A$. serpens (Lab) therefore contradict the species' occurrence in nature and its interspersed growth with other mosses, that can be attributed to the low competitiveness of $A$. serpens.

Compared to the other five studied species, $O$. hians had a low LAI of 7.151. B. rutabulum and E. striatum were similar in their LAI of 12.504 and 11.182 , respectively, and highest LAI values were determined for $A$. serpens (Lab) (14.572), O. hians (Lab) (14.048) and $P$. undulatum (14.585). Interestingly, $P$. undulatum and the two lab-grown mosses are very different in terms of leaf area, leaf frequency and shoot density, but all have similar LAI values. Considering the moss cushion density, $A$. serpens (Lab) was significantly denser than E. striatum $(\mathrm{p}<$ $0.001)$, O. hians $(\mathrm{p}<0.001)$ and P. undulatum $(\mathrm{p}<0.01)$. Furthermore, we found significant differences in regard to moss cushion density between $O$. hians (Lab) and E. striatum (p < $0.01)$, O. hians $(\mathrm{Lab})$ and O. hians $(\mathrm{p}<0.05)$, B. rutabulum and E. striatum $(\mathrm{p}<0.05)$ and E. striatum and P. undulatum $(\mathrm{p}<$ $0.05)$.

\section{Maximum water storage capacity}

Mean values of $\mathrm{WSC}_{\max }$ from the immersion technique (representing complete soaking) varied between $14.10 \mathrm{~g} \mathrm{~g}^{-1}$ for $A$. serpens (Lab) and $7.31 \mathrm{~g} \mathrm{~g}^{-1}$ for $P$. undulatum, with the difference being highly significant $(\mathrm{p}<0.001)$ (Fig. 2 and Table S2 in the supporting information). Further significant differences were found between E. striatum $\left(11.22 \mathrm{~g} \mathrm{~g}^{-1}\right)$ and $P$. undulatum as well as between $B$. rutabulum $\left(11.80 \mathrm{~g} \mathrm{~g}^{-1}\right)$ and $P$. undulatum $(\mathrm{p}<0.05)$. Thus, with regard to the $\mathrm{WSC}_{\max }$, there were strong differences between the mosses with different growth forms, but none within the group of pleurocarpous mosses. The fact 

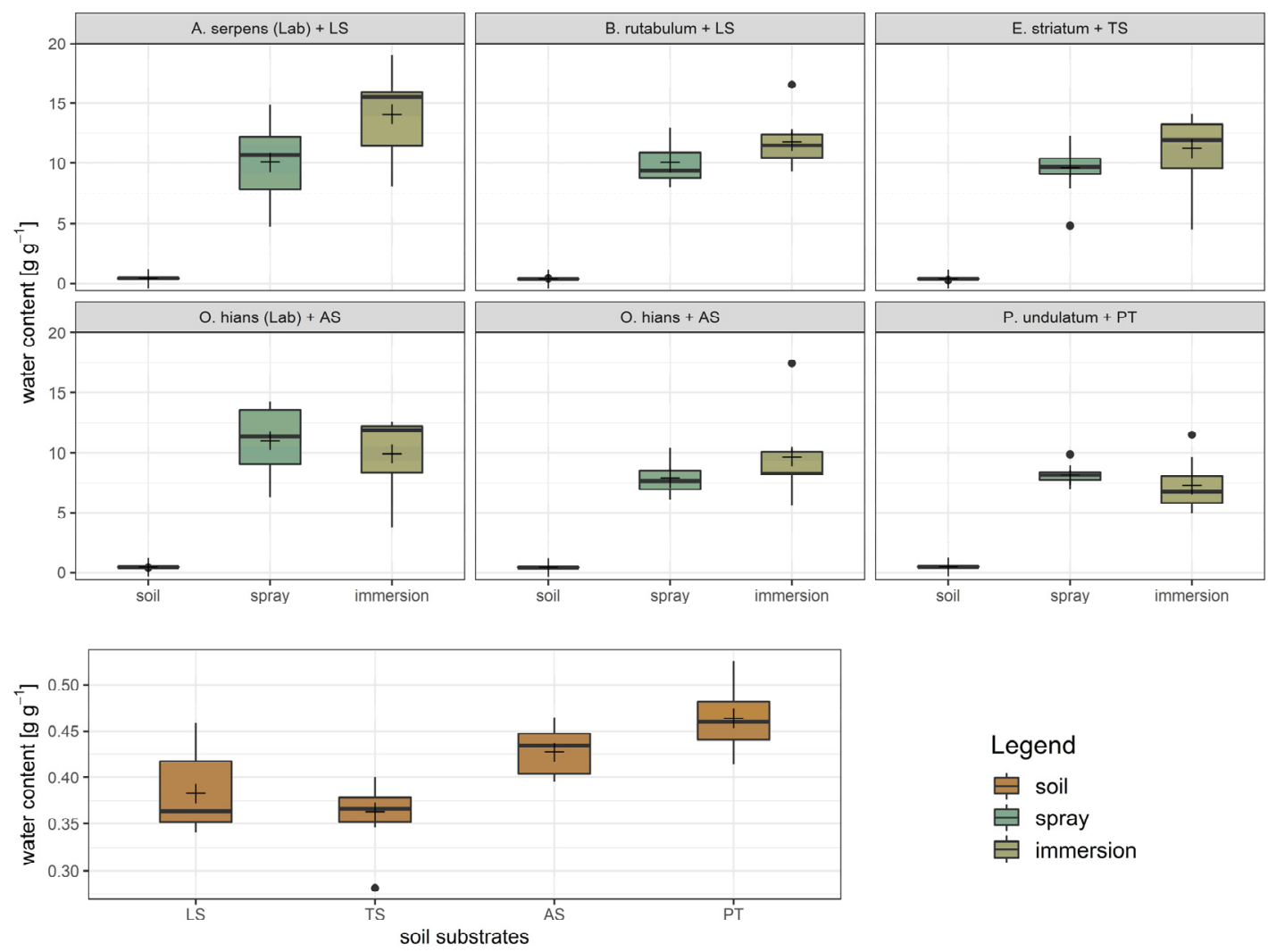

Fig. 2. Maximum water storage capacity $\left(\mathrm{g} \mathrm{g}^{-1}\right)$ of treatments (moss species + soil substrate). For moss species both spray and immersion technique are illustrated. Crosses represent mean values and lines within boxplots median values. The bottom and top of the box represent the first and third quartiles, and whiskers extend up to 1.5 times the interquartile range (IQR) of the data. Outliers are defined as more than 1.5 times the IQR and are displayed as points.

that $P$. undulatum absorbed comparatively less water could be explained by its endohydric water transport, and many acrocarpous mosses are endohydric (Richardson, 1981). Since the surface of endohydric mosses comprises a water-resistant cuticle with often waxy layers (Buch, 1945; Proctor, 1979a; $1979 \mathrm{~b}$ ), water absorption through their leaves is inhibited (Glime, 2017). However, as we only measured one acrocarpous moss, this finding requires further investigation.

Although the most significant difference in $\mathrm{WSC}_{\max }$ was shown between the visibly densest and loosest growing moss species, this relationship could not be substantiated by the surveyed traits for surface area and cushion characteristics. WSC $_{\max }$ was not affected by total surface area or LAI. Furthermore, neither height of the moss cushions, nor volume or density correlated individually with $\mathrm{WSC}_{\max }$. The combination of leaf area and leaf frequency seemed to have a higher influence on $\mathrm{WSC}_{\max }$ : with a small leaf area (Spearman's correlation rho $=-0.30, p<0.05$ ) and high leaf frequency (Spearman's correlation rho $=0.32, \mathrm{p}<0.05$ ), the $\mathrm{WSC}_{\max }$ increased. Shoot density might be another influencing factor, but due to small sample size further studies are recommended. In this context, Voortman et al. (2014) also discussed that capillary spaces between moss leaves and branches might be more relevant for water retention than those between moss shoots. For Sphagnum species, Bengtsson et al. (2020) also found a high influence of leaf traits on water retention.

Calculated in a GAM explaining $54.1 \%$ of the deviance, moss cushion density highly influenced $\mathrm{WSC}_{\max }(\mathrm{p}<0.001)$, while the effects of mean leaf area $(p<0.01)$ and mean shoot density $(p<0.05)$ were smaller, but also significant. Therefore, we assume that additional parameters must be also of great importance to the $\mathrm{WSC}_{\max }$. Such parameters are assumed to be, for example, the capillary spaces of mosses, which are very difficult to quantify and are diverse and often complex (Proctor, 1982). According to Proctor (1982), capillary conducting systems such as spaces between overlapping leaves, between shoots, in sheathing leaf bases or amongst rhizoid tomentum and paraphyllia can be 10-100 $\mu \mathrm{m}$ large. In addition, interspaces of a few $\mu \mathrm{m}$ can be found in interstices between papillae as well as in furrows between plicae and ridges on leaves and stems (Proctor, 1982). In this context, the 3D structure of the mosses, e.g. the branching of the shoots, the shape of the leaves and the position of the leaves in relation to the stems, potentially plays an important role for capillarity of bryophytes (Giordano et al., 1993; Schofield, 1981).

In contrast to the immersion technique, the range of mean values of $\mathrm{WSC}_{\max }$ for the spray technique, which was intended to simulate moistening of mosses by a rainfall event, was considerably smaller (Fig. 2). Here, we found a variation of 11.04 $\mathrm{g} \mathrm{g}^{-1}$ for $O$. hians (Lab) to $7.90 \mathrm{~g} \mathrm{~g}^{-1}$ for $O$. hians from the field. However, we could not find any significant differences between species or significant correlations between the $\mathrm{WSC}_{\max }$ and the ascertained individual moss structure parameters, and the adjunct GAM could explain $46.5 \%$ of the deviations. The greatest influence was due to moss height $(\mathrm{p}<0.01)$, with LAI having a smaller effect $(\mathrm{p}<0.05)$. Interestingly, the greatest difference in $\mathrm{WSC}_{\max }$ was discovered within the same species, $O$. hians. Although they belong to the same species, $O$. hians collected in the field and $O$. hians grown in the laboratory displayed strong differences in structure. While $O$. hians grows as loose lawn in the field, the laboratory variety forms very dense moss cushions, which is also reflected in the higher shoot density 
(O. hians: 4.714 shoots per $\mathrm{cm}^{2}$ and $O$. hians (Lab): 10.368 shoots per $\left.\mathrm{cm}^{2}\right)$, and the larger total surface area $(O$. hians: $169.907 \mathrm{~cm}^{2}$ and $O$. hians (Lab): $333.764 \mathrm{~cm}^{2}$ ). This finding indicates that the $\mathrm{WSC}_{\max }$ of mosses is dependent on life form. In a further chain of thought, this also implies that single species can obtain more advantageous properties through laboratory cultivation, e.g. for erosion control.

Overall, we suppose that for both the immersion technique and the spray technique, the capillary spaces between moss shoots as well as between leaves and shoots are more important for $\mathrm{WSC}_{\max }$ than surface parameters such as LAI or total surface area. Finally, it can be concluded that a further development and standardization of the spray technique is required to be able to gather more reliable data on this important moss characteristic.

Regarding the soil substrates, $\mathrm{WSC}_{\max }$ values varied on average between $0.46 \mathrm{~g} \mathrm{~g}^{-1}$ for PT and $0.36 \mathrm{~g} \mathrm{~g}^{-1}$ for TS, which is 30 times less compared to the $\mathrm{WSC}_{\max }$ of the mosses (Fig. 3). Within soil substrates we found highly significant differences between PT and TS, PT and LS as well as AS and TS $(p<0.001)$ and a significant difference between AS and TS $(\mathrm{p}<0.05)$. On one hand, these differences can be explained by soil texture, as there is a negative relationship with sand content (Spearman's correlation rho $=-0.62, \mathrm{p}<0.001$ ) and a positive correlation with silt content (Spearman's correlation rho $=0.52$, $\mathrm{p}<0.001$ ), while the clay content seemed to be of rather minor importance for $\mathrm{WSC}_{\max }$ (Spearman's correlation rho $=-0.40, \mathrm{p}$ $<0.01)$. On the other hand, we revealed a negative correlation with bulk density (Pearson's correlation $\mathrm{r}=-0.70, \mathrm{t}_{39}=-5.94, \mathrm{p}$ $<0.001$ ) and $\mathrm{C} / \mathrm{N}$ ratio (Spearman's correlation rho $=-0.62, \mathrm{p}$ $<0.001)$. Additionally, we tested for a joint impact on soil $\mathrm{WSC}_{\max }$ using a GAM with soil bulk density, sand, silt and clay contents as well as total carbon and nitrogen content as fixed effects and were able to explain $84.7 \%$ of the deviance with this model. The results also showed a high relevance of bulk soil density as well as total carbon content $(\mathrm{p}<0.001)$, which is consistent with the results of the individually tested correlations and an influence of the clay content $(\mathrm{p}<0.01)$. These relationships are also reported in other studies (Gong et al., 2003; Franzluebbers, 2002; Novák and Hlaváčiková, 2019; Rawls et al., 2003).

\section{Greenhouse experiment Watering process}

Focusing on the 60 minutes of watering, we observed clear differences in WC of different moss species, regarding temporal progression as well as the level of WC achieved (Fig. 3). At the beginning of the watering, all moss species were desiccated, so that the WC initially increased until an equilibrium was reached. Moss species were classified in terms of WC in equilibrium: (a) low WC $\left(0-5 \mathrm{~g} \mathrm{~g}^{-1}\right)$ for $A$. serpens (Lab) and $P$. undulatum, (b) medium WC (5-10 $\left.\mathrm{g} \mathrm{g}^{-1}\right)$ for B. rutabulum, $O$. hians and $O$. hians $(\mathrm{Lab})$, (c) high WC $\left(10-15 \mathrm{~g} \mathrm{~g}^{-1}\right)$ for $E$. striatum. This classification shows the possibility of distinguishing between moss species based on the BWP response.
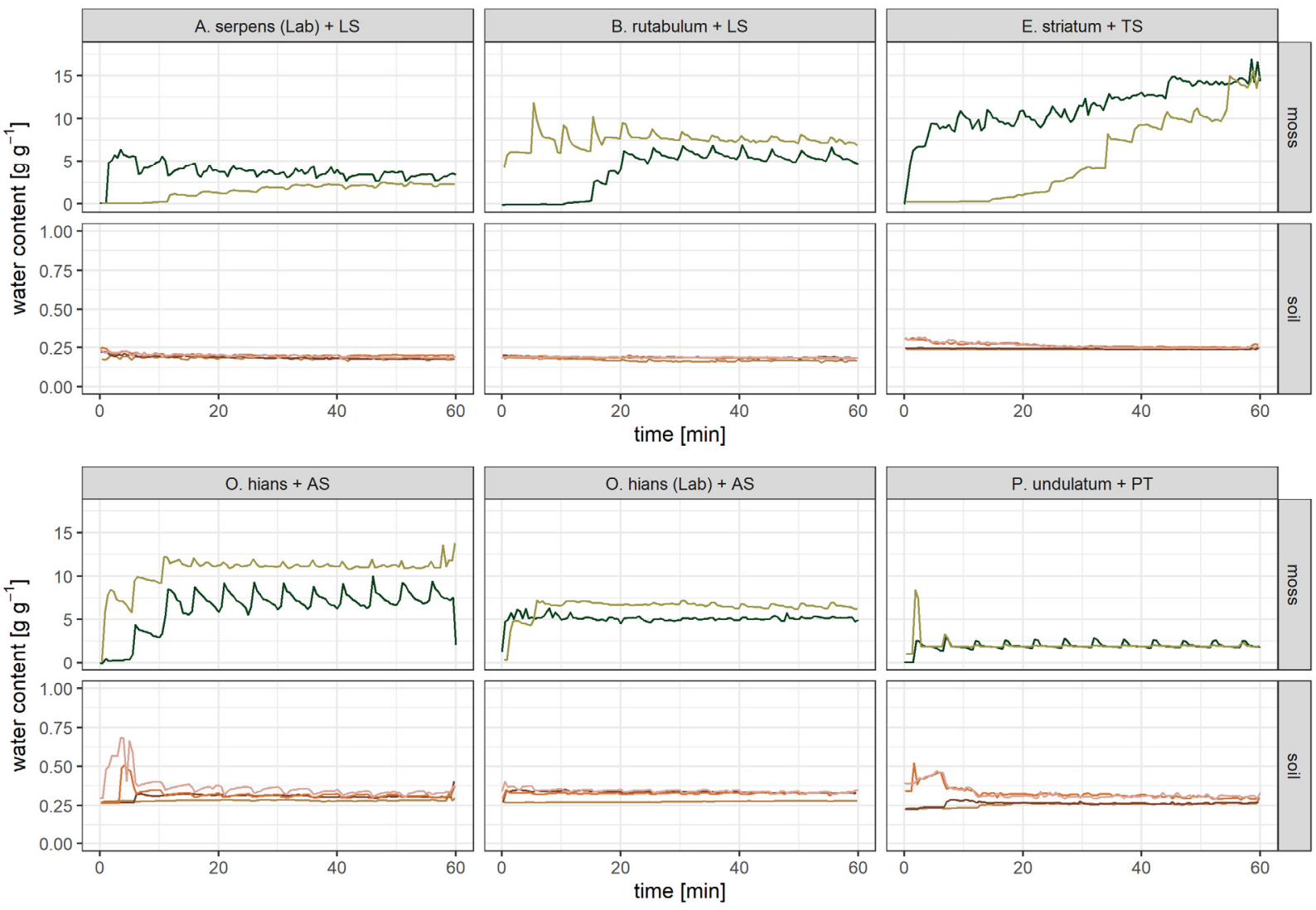

sensor location $-\operatorname{moss} A-\operatorname{soil} A-\operatorname{sol}$ surface A

Fig. 3. Temporal progression of water content values $\left(\mathrm{g} \mathrm{g}^{-1}\right)$ of treatments during watering in the greenhouse experiment. Replicate measurements are labelled with A and B for every biocrust wetness probe (BWP) location (moss cover, soil surface, $3 \mathrm{~cm}$ soil depth). Plotted are half-minute values. 
Surprisingly, A. serpens (Lab) and $P$. undulatum both reached a low WC during irrigation, although they are quite different regarding their structural traits. While $A$. serpens (Lab) forms very dense moss cushions (shoot density: $97.005 \pm 11.786$ shoots per $\mathrm{cm}^{2}$ ), $P$. undulatum is more likely to grow single shoots (shoot density: $3.087 \pm 0.827$ shoots per $\mathrm{cm}^{2}$ ). Although $O$. hians and $O$. hians (Lab) were both assigned to medium WC, we recognized a distinct difference, with $O$. hians tending to weigh $10 \mathrm{~g} \mathrm{~g}^{-1}$ and $O$. hians (Lab) tending to weigh $5 \mathrm{~g} \mathrm{~g}^{-1}$. Since $O$. hians $(\mathrm{Lab})$ grows considerably denser than $O$. hians with a shoot density twice as high $\left(O\right.$. hians $(\mathrm{Lab})=10.368 \pm 2.509$ shoots per $\mathrm{cm}^{2}, O$. hians $=$ $4.714 \pm 0.712$ shoots per $\left.\mathrm{cm}^{2}\right)$ and a higher cushion density $(O$. hians $(\mathrm{Lab})=0.022 \pm 0.003$ shoots per $\mathrm{cm}^{2}, O$. hians $=0.015 \pm$ 0.002 shoots per $\mathrm{cm}^{2}$ ), we expected that $O$. hians (Lab) would also absorb more water during watering. The fact that this expectation was not fulfilled could be attributed to $O$. hians having a comparatively high leaf frequency with small leaf area, which had already been highlighted as important factors for water absorption in previous chapters.

Furthermore, almost all moss species showed a certain variation in WC at equilibrium within replicate measurements, illustrating a great heterogeneity within species. Overall, we noticed that the variations between replicate measurements were smaller for denser moss cushions than for looser ones, with $P$. undulatum being an exception in this case. This could be attributed to the fact that denser mosses establish better contact with the sensor without forming air spaces (Löbs et al., 2020).

Some moss species demonstrated a more pronounced response to the watering pulses than others. This might also be related to denser moss cushions with less air-filled interstitial spaces (Löbs et al., 2020), as it was the case for $A$. serpens (Lab) and $O$. hians (Lab), which both form the densest cushions. To examine moss intraspecific differences regarding water absorption in detail, higher replication is necessary in future studies.

Because of the water volume applied to the samples in the greenhouse, we speculated that the moss species would reach their $\mathrm{WSC}_{\max }$ within the watering time in the greenhouse, especially when compared with the achieved $\mathrm{WSC}_{\max }$ using the spray technique. To go into more detail, we compared the WC values directly after watering (means of $\mathrm{WC}$ for all values between $60^{\text {th }}$ and $65^{\text {th }}$ minute) with the $\mathrm{WSC}_{\max }$ determined in the lab. For most of the species the WC after watering was considerably lower than the $\mathrm{WSC}_{\max }$, for both spray and immersion technique. As an example, the maximum WC for $A$. serpens using the immersion technique was 5 times higher than the $\mathrm{WC}$ after watering $\left(\mathrm{WSC}_{\max }\right.$ (immersion) $=14.10 \mathrm{~g} \mathrm{~g}^{-1}, \mathrm{SE}=$ 1.28 , WC after watering $=2.63 \mathrm{~g} \mathrm{~g}^{-1}, \mathrm{SE}=0.02$ ), while the spray technique showed almost a fourfold difference (WSC $\mathrm{Wax}_{\max }$ (spray) $=10.10 \mathrm{~g} \mathrm{~g}^{-1}, \mathrm{SE}=1.25$ ). Additionally, we found an almost fivefold difference from the immersion technique, respective fourfold difference from the spray technique, and higher $\mathrm{WSC}_{\max }$ compared to the WC after watering in $P$. undulatum $\left(\mathrm{WSC}_{\max }\right.$ (immersion) $=7.31 \mathrm{~g} \mathrm{~g}^{-1}, \mathrm{SE}=0.80, \mathrm{WSC}_{\max }$ (spray) $=8.15 \mathrm{~g} \mathrm{~g}^{-1}, \mathrm{SE}=0.32, \mathrm{WC}$ after watering $=1.76 \mathrm{~g} \mathrm{~g}^{-1}$, $\mathrm{SE}=0.01)$. Based on these results, no clear patterns are discernible that would explain the different intraspecific mechanisms of water absorption comparing greenhouse and laboratory experiments. Above all, it was very surprising that especially the denser mosses, most notably the lab-grown mosses, did not absorb much water during the greenhouse experiment. In general, we can deduce that the mosses are not a barrier to infiltration in case of high precipitation rates, as also reported in Li et al. (2016). A new observation of our study is that the mosses growing on the soil do not store much of the applied water themselves, but pass it on to the soil.
Compared to the mosses, the soil substrates showed a much lower WC during the 60 minutes of watering, which is true for both the surface and $3 \mathrm{~cm}$ soil depth (Fig. 3). Overall, mosses adjusted their equilibrium in the range between $2.5-15.0 \mathrm{~g} \mathrm{~g}^{-1}$ of WC, while soil substrates varied between $0.15-0.35 \mathrm{~g} \mathrm{~g}^{-1}$. The fact that mosses can absorb more water than soil substrates could be attributed to a larger surface area of mosses. Additionally, capillary effects in mosses might contribute to higher water absorption rates compared to soil substrates.

Since the soil surfaces were not completely dried out at the beginning of the experiment, they showed a relatively high starting value of WC in comparison with the later reached equilibrium. The temporal progression of $\mathrm{WC}$ on the soil surface started with higher values at the beginning of watering and slightly decreased over time. Regarding infiltration into the soil surface, it appeared that water had initially accumulated on the surface, causing the high WC.

When considering WC at $3 \mathrm{~cm}$ soil depth, temporal progression of WC was almost steady, which was also due to the already wet soil substrate at the beginning of the experiment. For two substrates (AS and PT) we observed an increase of WC during the first 10 minutes of irrigation, indicating percolation of water through the substrate. Additionally, WC tended to be lower at $3 \mathrm{~cm}$ soil depth than on the soil surface during irrigation. Overall, with respect to the temporal progression of WC values on soil surface and in $3 \mathrm{~cm}$ soil depth, we generally found substrate-specific coherences regarding the level of WC achieved.

Furthermore, we expected that the soil substrates show a similar response due to $\mathrm{WSC}_{\max }$ in the lab and in the greenhouse experiment. However, the WC after watering in the greenhouse, which we expected to be the maximum WC reached in the greenhouse (means of WC for all values between $60^{\text {th }}$ and $65^{\text {th }}$ minute), were lower than the $\mathrm{WSC}_{\max }$ measured in the lab, which was true for every substrate both for surface as well as in $3 \mathrm{~cm}$ soil depth. For example, PT achieved a $\mathrm{WSC}_{\max }$ of $0.46 \mathrm{~g} \mathrm{~g}^{-1}$ and only showed a WC of $0.31 \mathrm{~g} \mathrm{~g}^{-1}$ on the surface and $0.27 \mathrm{~g} \mathrm{~g}^{-1}$ in the soil after one hour of watering in the greenhouse, which means a deviance of $32.61 \%$. In comparison, LS reached only $50 \%$ of the $\mathrm{WSC}_{\max }$ under $A$. serpens $(\mathrm{Lab})\left(\mathrm{WC}\right.$ after watering $=0.19 \mathrm{~g} \mathrm{~g}^{-1}, \mathrm{WSC}_{\max }=0.46 \mathrm{~g} \mathrm{~g}^{-1}$ ) and $52 \%$ under B. rutabulum on the surface (WC after watering $=0.18 \mathrm{~g} \mathrm{~g}^{-1}$ ), WC values in $3 \mathrm{~cm}$ soil depth were even lower (WC after watering $(A$. serpens $(\mathrm{Lab}))=0.18 \mathrm{~g} \mathrm{~g}^{-1}$; WC after watering $(B$. rutabulum $\left.)=0.17 \mathrm{~g} \mathrm{~g}^{-1}\right)$. Altogether, soil substrates did not show the same patterns of water absorption in the lab as in the greenhouse.

\section{Desiccation process}

During the subsequent desiccation process of 71 hours, moisture in the moss layers generally decreased, while moisture at the soil substrate surface as well as in $3 \mathrm{~cm}$ soil substrate depth remained at the same levels (Fig. 4). However, moss species differed in maximum $\mathrm{WC}$, evaporation rates and their responses to climatic changes in the greenhouse. Sample replicates slightly differed from each other in regard to WC values, but generally showed comparable patterns. We observed the highest WC values directly after watering in E. striatum with a mean WC of almost $15 \mathrm{~g} \mathrm{~g}^{-1}$, while mean WC of B. rutabulum, $O$. hians and $O$. hians (Lab) ranged between $5-10 \mathrm{~g} \mathrm{~g}^{-1}$, and mean WC of $A$. serpens (Lab) and $P$. undulatum did not exceed $5 \mathrm{~g} \mathrm{~g}^{-1}$. The low WC of $P$. undulatum might be related to its delicate and loose structure with a low leaf frequency and large leaf areas, and leaves that stand off the shoot. Especially 

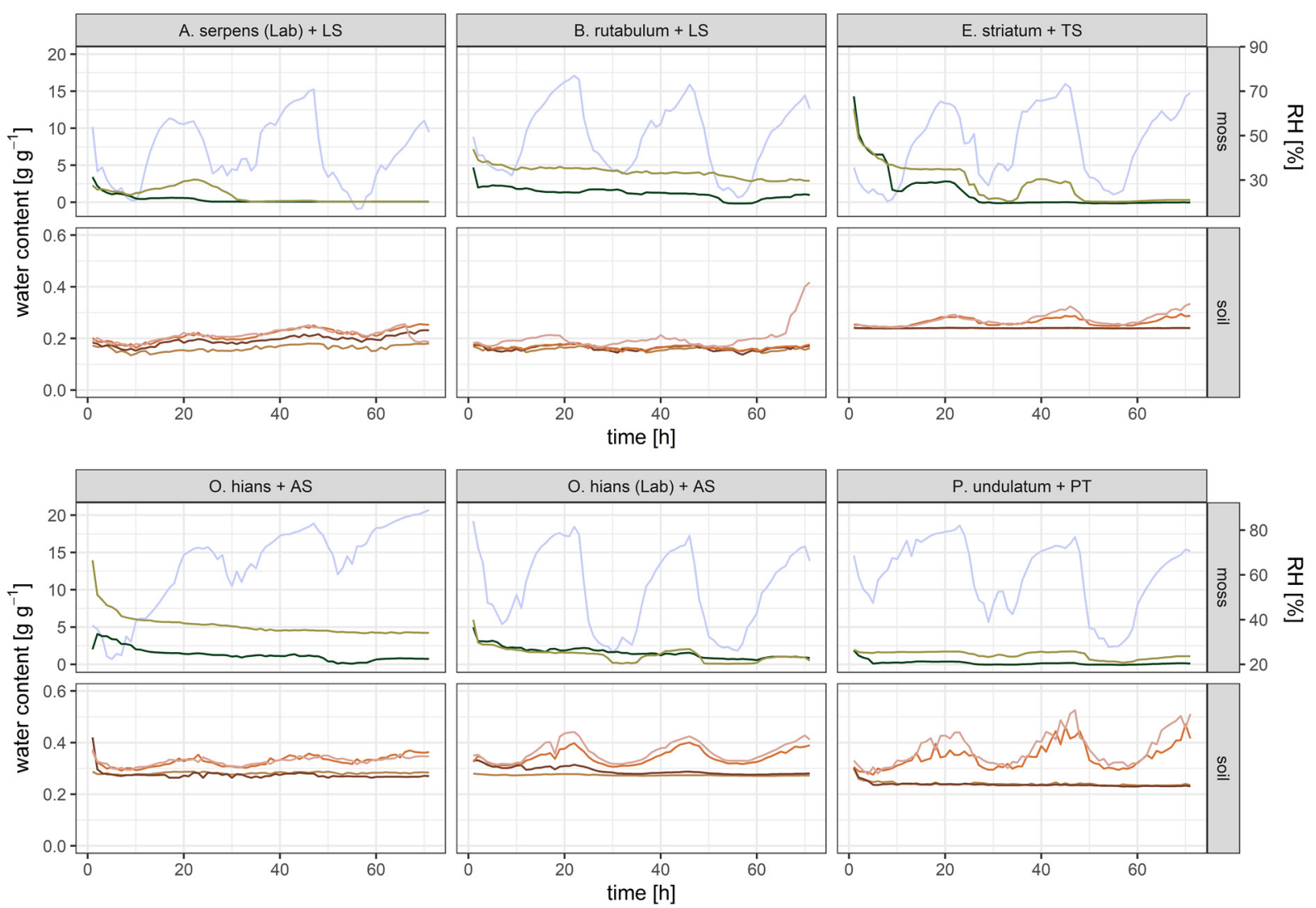

sensor location

- moss A - soil A - soil surface A
$-\operatorname{moss} B-$ soil B - soil surface B

Fig. 4. Temporal progression of water content values $\left(\mathrm{g} \mathrm{g}^{-1}\right)$ of treatments during $71 \mathrm{~h}$ of desiccation in the greenhouse experiment. Replicate measurements are labelled with A and B for every biocrust wetness probe (BWP) location (moss cover, soil surface, $3 \mathrm{~cm}$ soil depth). Mean temperature and mean relative humidity \pm standard deviation: Amblystegium serpens $(\mathrm{Lab})+$ Löwenstein-Formation (LS) $25.93 \pm$ $6.13{ }^{\circ} \mathrm{C}, 42.67 \pm 14.39 \%$; Brachythecium rutabulum + Löwenstein-Formation (LS) $26.35 \pm 5.38{ }^{\circ} \mathrm{C}, 49.45 \pm 15.22 \%$; Eurhynchium striatum + Trossingen-Formation (TS) $24.70 \pm 5.78{ }^{\circ} \mathrm{C}, 46.31 \pm 16.15 \%$; Oxyrrhynchium hians + Angulatensandstein-Formation (AS) $20.30 \pm$ $3.89^{\circ} \mathrm{C}, 64.72 \pm 18.45 \%$; Oxyrrhynchium hians (Lab) + Angulatensandstein-Formation (AS) $23.10 \pm 6.07{ }^{\circ} \mathrm{C}, 53.37 \pm 18.38 \%$; Plagiomnium undulatum + Psilonotenton-Formation (PT) $20.96 \pm 4.31^{\circ} \mathrm{C}, 59.92 \pm 15.35 \%$. Plotted are hourly values.

compared to a branched structure with high leaf frequencies and densely attached leaves, few capillary spaces for water storage are formed in $P$. undulatum (Mägdefrau and Wutz, 1951). Furthermore, leaf surfaces of mosses from the Mniaceae family often have a water-resistant cuticle, reducing their ability to absorb water via the leaves (Glime, 2017; Proctor, 2000). Additionally, we observed that leaves and stems of $P$. undulatum were twisting and curling during the desiccation process, which might result in altered measurement conditions for the sensor. Clipping the sensor to moss stems of such species as $P$. undulatum, as proposed in Leo et al. (2019), would be interesting to compare with BWP response in future studies. Nevertheless, the BWP used in this study proved to be successful in all moss species, as also confirmed in Löbs et al. (2020).

A. serpens (Lab) had dried out after 30 hours, whereas the other species generally remained moist longer than 40 hours, and did not desiccate completely during the measurement. A more stabilized, steady evaporation was observed in B. rutabulum, O. hians, O. hians (Lab) and P. undulatum. Evaporation rates calculated for the measurement period corresponded to maximum WC: E. striatum with the highest maximum WC after watering also had the highest evaporation rates $(0.181-$ $\left.0.197 \mathrm{~g} \mathrm{~h}^{-1}\right)$. Evaporation rates for P. undulatum were consider- ably smaller $\left(0.023\right.$ and $\left.0.012 \mathrm{~g} \mathrm{~h}^{-1}\right)$. A group with slightly higher evaporation rates consisted of $A$. serpens (Lab) $(0.056$ and $\left.0.03 \mathrm{~g} \mathrm{~h}^{-1}\right)$, B. rutabulum $\left(0.046\right.$ and $\left.0.055 \mathrm{~g} \mathrm{~h}^{-1}\right), O$. hians (Lab) $\left(0.057\right.$ and $\left.0.078 \mathrm{~g} \mathrm{~h}^{-1}\right)$ and $O$. hians (0.06 and 0.093 $\left.\mathrm{g} \mathrm{h}^{-1}\right)$. We found a positive relationship between leaf frequency and evaporation rate (Spearman's correlation rho $=0.832, \mathrm{P}<$ 0.001). LAI, however, correlated negatively with evaporation rate (Spearman's correlation rho $=-0.78, \mathrm{P}<0.001$ ); this was congruent with our expectations of lower evaporation rates for moss species with a high LAI, which, as a product of different structural traits, makes the formation of a multitude of capillary spaces for water storage in different hierarchical levels (leaf, shoot, and colony) more likely, overall resulting in wetter moss cushions and lower evaporation rates, as also described in Elumeeva et al. (2011).

WC in moss species showed diel fluctuations, albeit to different degrees. Desiccation periods clearly aligned with declining RH and rising temperatures in E. striatum, O. hians (Lab), and to a smaller degree in P. undulatum, A. serpens (Lab), B. rutabulum and $O$. hians. Comparably high RH and low temperatures contributed to the quite stable WC of $O$. hians throughout the measurement and to the fact that the moss did not dry completely. We observed slight reactions of WC towards RH changes in all samples, confirming that mosses 
reacted to increasing $\mathrm{RH}$ and could absorb water under conditions with high $\mathrm{RH}$, as also described in Löbs et al. (2020).

Climatic conditions cannot explain intraspecific variation of WC, since the replicates were measured in parallel at the same time. A possible explanation could be that moss structure at the sensor locations differed in regard to surface roughness, altering boundary layer resistance and thus resulting in different evaporation velocities (Proctor, 1982). Further experiments in a climate-controlled environment with closer control and manipulation possibilities could determine if moss reactions are species-specific.

The different soil substrates had slightly different mean WC values in $3 \mathrm{~cm}$ depth: LS $0.16-0.18 \mathrm{~g} \mathrm{~g}^{-1}$, TS $0.24 \mathrm{~g} \mathrm{~g}^{-1}$, AS $0.28 \mathrm{~g} \mathrm{~g}^{-1}$ and PT $0.24 \mathrm{~g} \mathrm{~g}^{-1}$. In LS, a slight reaction to rising RH (due to night-day-shifts) was recognizable, and LS did not desiccate, despite high temperatures above $40{ }^{\circ} \mathrm{C}$ during the measurement period. We assume that the moss cover prevented desiccation of the substrate, but it remains unclear whether the substrate receives water from the moss cushion itself or plainly from RH. For low precipitation rates, prevention of soil evaporation from moss-dominated biocrusts was also reported in $\mathrm{Li}$ et al. (2016).

WC at the soil surface fluctuated diurnally depending on RH as also described in Tucker et al. (2017), especially in AS and PT and less pronounced in LS. Moreover, we found that oscillations related to RH were visible at the soil surface but not in $3 \mathrm{~cm}$ soil depth, which showed that fine pores at the surface were capable of adsorbing water out of the air (Agam and Berliner, 2006; Hillel, 1998). So even dense moss cushions were not completely sealing the soil surface and there was no full barrier by bryophytes. However, since the RH-induced fluctuations varied depending on the density of the moss cover, i.e. the most pronounced reactions were found in the loosest moss cover $P$. undulatum, we assume that mosses mitigate soil evaporation.

Generally, WC at the soil surface was higher than in $3 \mathrm{~cm}$ depth during desiccation. This could be ascribed to the fact that the soil surface had a finer texture due to clogging of the pores as an influence of splash effects (Morgan, 2005), which allows for a higher WC (Dodd and Lauenroth, 1997). A further influencing factor to explain this observation might be the initial soil WC. As we measured a high soil WC before watering, the matrix potential is reduced, resulting in a lower and less deep infiltration (Novák and Hlaváčiková, 2019).

Differences between WC values of surface and $3 \mathrm{~cm}$ depth depended on the substrate: for LS, the values were very similar, but especially for PT, WC values at substrate surface were higher than in $3 \mathrm{~cm}$ depth by a factor of 1.4 to 2.3. In AS, there was either an influence by the moss cover, or by the climatic conditions during the measurement: AS covered with $O$. hians showed a smaller difference between surface and soil WC and not very pronounced oscillations with RH. In contrast, AS covered with $O$. hians (Lab) displayed strong day-night oscillations and $\mathrm{WC}$ values during nights were up to 1.5-times higher in the surface than in $3 \mathrm{~cm}$ depth. Since RH remained above $50 \%$ after 20 hours during the measurement of AS with $O$. hians, but dropped from $75 \%$ in the nights to $25 \% \mathrm{RH}$ during the days in the measurement of AS with O. hians (Lab), we cannot exclude a strong influence of these fluctuations on the different oscillation patterns in the AS measurements. To determine the effect of moss layers itself on soil substrate moistness and evaporation, an experiment with different moss species on similar substrates and control samples without moss is necessary.

\section{CONCLUSIONS AND OUTLOOK}

This study found that five moss species from Central European temperate forests can exhibit different water absorption and evaporation patterns in response to rainfall. In some cases, the target moss species also showed significant intraspecific variability in rainwater interception. With regard to our hypotheses, the following conclusions were drawn:

1. Contradictory to our hypothesis, total surface area did not affect maximum water storage capacity ( $\mathrm{WSC}_{\max }$ ). Results further indicate that a combination of structural traits (high shoot density, high leaf frequency, and low leaf area) may increase $\mathrm{WSC}_{\max }$ during immersion. Generalized additive models (GAM) revealed that cushion density also can influence $\mathrm{WSC}_{\max }$. A combination of different structural traits tested in a GAM showed that $\mathrm{WSC}_{\max }$ determined using the spray technique was affected by leaf area index (LAI) and moss height. Overall, soil substrates absorbed around 30 times less water compared to mosses and an effect of bulk density, grain size distribution and total carbon content on $\mathrm{WSC}_{\max }$ was found.

2. Both moss species and soil substrates showed species/substrate-specific patterns in regard to changes of moisture during watering as well as desiccation. Since soil substrates did not desiccate despite high temperatures, yet water content at the surface responded to relative humidity changes, we hypothesize that the moss cover prevented desiccation without sealing the soil. Because the humidity-induced fluctuations varied depending on the density of the moss cover, we further hypothesize that mosses mitigate soil evaporation. Among moss species, differences were also observed between replicates, primarily related to the moistening until an equilibrium in water content was reached, as well as in the process of desiccation. Similar $\mathrm{WSC}_{\max }$ values (to immersion and spray) were not achieved in greenhouse experiments during watering, indicating different mechanisms of water absorption for both soil substrates and moss species, which could not be explained by clear patterns. In general, we can deduce that the mosses growing on the soil may not store much of the applied water themselves, but pass it on to the soil. Leaf frequency correlated positively with evaporation rates, while LAI showed a negative relationship with evaporation rates.

Although not explicitly mentioned in our hypotheses, the results underscore that some species can develop different morphologies due to different growing locations (field vs. laboratory). This can lead to a heterogeneous expression of the same traits and raises the question of whether beneficial traits can be conferred to individual species by laboratory cultivation, e.g. for erosion control. Thus, the interplay of individual moss structure traits appears to be very complex, such that further detailed investigations especially on the 3D structure of individual species are urgently needed. In this context, more information on moss capillary spaces would help to achieve a higher level of accuracy regarding the mechanisms of water absorption in mosses. It should be noted that the methodology also needs further improvement and the exact determination of individual species effects can be seen as non-trivial.

Considering that the methodology has proven to be sound, the full significance of the current results in this study needs to be confirmed in a larger experimental setup. Further research is required to understand the details of how different moss species and soil substrates interact regarding water absorption and evaporation. A multi-method approach to measure water content in different layers is recommended, using biocrust wetness probes as well as clip sensors for the moss cover as introduced 
by Leo et al. (2019). This approach should be combined with the use of a climate-regulated greenhouse and expanded to include control samples without moss cover and large number of replicates in order to cover the existing complexity as well as possible. This complexity is also the major challenge in the investigation of "water's path from moss to soil", to the understanding of which this study has made a further contribution.

Acknowledgements. We thank Michael Sauer for his assistance and expertise during moss sample collection, Lena Grabherr and Sarah Fodor for their support in measuring moss structural parameters, Daniel Schwindt for helpful comments and Matthew Hughes for improving the language of the manuscript. We are also grateful to the Plant Ecology group of the University of Tübingen for the space provided in their greenhouse. We thank three anonymous reviewers for their constructive comments. This study was funded by the German Research Foundation (DFG SE 2767/2-1 "MesiCrust") and the Federal Ministry for Economic Affairs and Energy (AiF 19808 N).

\section{REFERENCES}

Acharya, B.S., Stebler, E., Zou, C.B., 2017. Monitoring litter interception of rainfall using leaf wetness sensor under controlled and field conditions. Hydrological Processes, 31, 240-249.

Agam, N., Berliner, P.R., 2006. Dew formation and water vapor adsorption in semi-arid environments - A review. Journal of Arid Environments, 65, 572-590.

Bates, J.W., 1998. Is 'life-form' a useful concept in bryophyte ecology? Oikos, 82, 223-237.

Belnap, J., Weber, B., Büdel, B., 2016. Biological soil crusts as an organizing principle in drylands. In: Weber, B., Büdel, B., Belnap, J. (Eds.): Biological Soil Crusts: An Organizing Principle in Drylands. Springer International Publishing, Cham, pp. 3-13.

Bengtsson, F., Granath, G., Cronberg, N., Rydin, H., 2020. Mechanisms behind species-specific water economy responses to water level drawdown in peat mosses. Annals of Botany, 126, 219-230.

Blume, H.-P., Stahr, K., Leinweber, P., 2011. Bodenkundliches Praktikum: eine Einführung in pedologisches Arbeiten für Ökologen, insbesondere Land- und Forstwirte, und für Geowissenschaftler. 3. neubearbeitete Auflage edn. Spektrum Akademischer Verlag, Heidelberg.

Bond-Lamberty, B., Gower, S.T., Amiro, B., Ewers, B.E., 2011. Measurement and modelling of bryophyte evaporation in a boreal forest chronosequence. Ecohydrology, 4, 26-35.

Buch, H.R.V., 1945. Über die Wasser- und Mineralstoffversorgung der Moose. Academic Bookstore, Helsinki.

Carleton, T., Dunham, K., 2003. Distillation in a boreal mossy forest floor. Canadian Journal of Forest Research, 33, 663671.

Cornelissen, J.H., Lang, S.I., Soudzilovskaia, N.A., During, H.J., 2007. Comparative cryptogam ecology: a review of bryophyte and lichen traits that drive biogeochemistry. Annals of Botany, 99, 987-1001.

Dilks, T.J.K., Proctor, M.C.F., 1979. Photosynthesis, respiration and water content in bryophytes. New Phytologist, 82, 97-114.

Dodd, M.B., Lauenroth, W.K., 1997. The influence of soil texture on the soil water dynamics and vegetation structure of a shortgrass steppe ecosystem. Plant Ecology, 133, 13-28.

Einsele, G., Agster, G., 1986. Überblick zur Geologie und
Morphologie des Schönbuchs. In: Einsele, G. (Ed.): Das landschaftsökologische Forschungsprojekt Naturpark Schönbuch: Wasser- und Stoffhaushalt, Bio-, Geo- und Forstwirtschaftliche Studien in Südwestdeutschland. VCH Verlagsfesellschaft, Weinheim.

Elbert, W., Weber, B., Burrows, S., Steinkamp, J., Büdel, B., Andreae, M.O., Pöschl, U., 2012. Contribution of cryptogamic covers to the global cycles of carbon and nitrogen. Nature Geoscience, 5, 459-462.

Elumeeva, T.G., Soudzilovskaia, N.A., During, H.J., Cornelissen, J.H., 2011. The importance of colony structure versus shoot morphology for the water balance of 22 subarctic bryophyte species. Journal of Vegetation Science, $22,152-164$.

Franzluebbers, A.J., 2002. Water infiltration and soil structure related to organic matter and its stratification with depth. Soil and Tillage Research, 66, 197-205.

Frey, W., Stech, M., Fischer, E., 2009. Syllabus of Plant Families - Part 3: Bryophytes and Seedless Vascular Plants. Borntraeger, Berlin, Stuttgart.

Gerrits, A.M.J., Savenije, H.H.G., 2011. Forest floor interception. In: Levia, D.F., Carlyle-Moses, D., Tanaka, T. (Eds.): Forest Hydrology and Biogeochemistry: Synthesis of Past Research and Future Directions. Springer Netherlands, Dordrecht, pp. 445-454.

Giordano, S., Colacino, C., Spagnuolo, V., Basile, A., Esposito, A., Castaldo-Cobianchi, R., 1993. Morphological adaptation to water uptake and transport in the poikilohydric moss Tortula ruralis. Giornale Botanico Italiano, 127, 1123-1132.

Glime, J.M., 2017. Volume 1: Physiological Ecology. Bryophyte Ecology.

Goetz, J.D., Price, J.S., 2015. Role of morphological structure and layering of Sphagnum and Tomenthypnum mosses on moss productivity and evaporation rates. Canadian Journal of Soil Science, 95, 109-124.

Gong, Y., Cao, Q., Sun, Z., 2003. The effects of soil bulk density, clay content and temperature on soil water content measurement using time-domain reflectometry. Hydrological Processes, 17, 3601-3614.

Green, T.G.A., Lange, O.L., 1994. Photosynthesis in poikilohydric plants: a comparison of lichens and bryophytes. In: Schulze, E.-D., Caldwell, M.M. (Eds.): Ecophysiology of Photosynthesis. Springer, New York, pp. 319-341.

Gundule, M.J., Deluca, T.H., Nordin, A., 2011. Bryophytes attenuate anthropogenic nitrogen inputs in boreal forests. Global Change Biology, 17, 2743-2753.

Gypser, S., Veste, M., Herppich, W., Kast, G., 2017. Linking of biological soil crust wetness and ecological performance on disturbed soils in Lower Lusatia, Germany. BES, GFÖ, NECOV, and EEF Joint Annual Meeting: Ecology across Borders. Ghent.

He, X., He, K.S., Hyvönen, J., 2016. Will bryophytes survive in a warming world? Perspectives in Plant Ecology, Evolution and Systematics, 19, 49-60.

Hedenäs, L., 2007. Global diversity patterns among pleurocarpous mosses. The Bryologist, 110, 319-331.

Hillel, D., 1998. Environmental Soil Physics: Fundamentals, Applications, and Environmental Considerations. Elsevier.

Leo, M., Lareo, A., Garcia-Saura, C., Hortal, J., Medina, N.G., 2019. BtM, a low-cost open-source datalogger to estimate the water content of nonvascular cryptogams. Journal of Visualized Experiments, 145, e58700.

Li, B., Gao, J., Wang, X., Ma, L., Cui, Q., Veste, M., 2016. Effects of biological soil crusts on water infiltration and 
evaporation Yanchi Ningxia, Maowusu Desert, China. International Journal of Sediment Research, 31, 311-323.

Lindo, Z., Gonzalez, A., 2010. The bryosphere: An integral and influential component of the Earth's biosphere. Ecosystems, 13, 612-627.

Liu, D., She, D., 2020. Combined effects of moss crusts and pine needles on evaporation of carbonate-derived laterite from karst mountainous lands. Journal of Hydrology, 586, 124859.

Löbs, N., Walter, D., Barbosa, C.G.G., Brill, S., Alves, R.P., Cerqueira, G.R., de Oliveira Sá, M., de Araújo, A.C., de Oliveira, L.R., Ditas, F., Moran-Zuloaga, D., Pires Florentino, A.P., Wolff, S., Godoi, R.H.M., Kesselmeier, J., Mota de Oliveira, S., Andreae, M.O., Pöhlker, C., Weber, B. 2020. Microclimatic conditions and water content fluctuations experienced by epiphytic bryophytes in an Amazonian rain forest. Biogeosciences, 17, 5399-5416.

Mägdefrau, K., 1982. Life-forms of bryophytes. In: Smith, A.J.E. (Ed.): Bryophyte Ecology. Springer, Dordrecht.

Mägdefrau, K., Wutz, A., 1951. Die Wasserkapazität der Moosund Flechtendecke des Waldes. Veröffentlichung des Botanischen Instituts der Forstl. Forschungsanstalt München.

Medina, N., Draper, I., Lara, F., 2011. Biogeography of mosses and allies: Does size matter? Biogeography of microscopic organisms. Is everything small everywhere? Cambridge University Press, pp. 209-233.

Morgan, R.P.C., 2005. Soil Erosion and Conservation. 3 edn. Blachwell Publishing, Oxford.

Nakatsubo, T., 1994. The effect of growth form on the evaporation in some subalpine mosses. Ecological Research, 9, 245-250.

Nebel, M., 2001. Amblystegium serpens (Hedw.) Schimp. In: Nebel, M., Philippi, G. (Eds.): Die Moose BadenWürttembergs, Band 2: Bryophytina II, Schistostegales bis Hypnobryales. Verlag Eugen Ulmer, Stuttgart, pp. 308-309.

Nebel, M., Philippi, G., Ahrens, M., Sauer, M., SchäferVerwimp, A., Schoepe, G., 2001. Die Moose BadenWürttembergs, Band 2: Bryophytina II, Schistostegales bis Hypnobryales. Verlag Eugen Ulmer, Stuttgart.

Niinemets, Ü., Tobias, M., 2014. Scaling light harvesting from moss "leaves" to canopies. In: Hanson, D.T., Rice, S.K. (Eds): Photosynthesis in Bryophytes and Early Land Plants. Advances in Photosynthesis and Respiration (Including Bioenergy and Related Processes). Springer, Dordrecht, pp. 151-171.

Niinemets, Ü., Tobias, M., 2019. Canopy leaf area index at its higher end: dissection of structural controls from leaf to canopy scales in bryophytes. New Phytologist, 223, 118133.

Novák, V., Hlaváčiková, H., 2019. Applied Soil Hydrology. Springer, Heidelberg, Berlin.

Oishi, Y., 2018. Evaluation of the water-storage capacity of bryophytes along an altitudinal gradient from temperate forests to the Alpine zone. Forests, 9, 14.

Price, A.G., Dunham, K., Carleton, T., Band, L., 1997. Variability of water fluxes through the black spruce (Picea mariana) canopy and feather moss (Pleurozium schreberi) carpet in the boreal forest of Northern Manitoba. Journal of Hydrology, 196, 310-323.

Proctor, M.C.F., 1979a. Structure and eco-physiological adaptation in bryophytes. In: Bryophyte Systematics. Academic Press, London, pp. 479-509.

Proctor, M.C.F., 1979b. Surface wax on the leaves of some mosses. Journal of Bryology, 10, 531-538.
Proctor, M.C.F., 1982. Physiological ecology: Water relations, light and temperature responses, carbon balance. In: Smith, A.J.E. (Ed.): Bryophyte Ecology. Springer, Dordrecht.

Proctor, M.C.F., 1990. The physiological basis of bryophyte production. Botanical Journal of the Linnean Society, 104, 61-77.

Proctor, M.C.F., 2000. The bryophyte paradox: tolerance of desiccation, evasion of drought. Plant Ecology, 151, 41-49.

Proctor, M.C.F., Nagy, Z., Csintalan, Z., Takács, Z., 1998. Water-content components in bryophytes: Analysis of pressure-volume relationships. Journal of Experimental Botany, 49, 1845-1854.

Proctor, M.C.F., Oliver, M., Wood, A., Alpert, P., Stark, L., Cleavitt, N., Mishler, B., 2007. Desiccation-tolerance in bryophytes: A review. The Bryologist, 110, 595-621.

Proctor, M.C.F., Tuba, Z., 2002. Poikilohydry and homoihydry: antithesis or spectrum of possibilities? New Phytologist, $156,327-349$.

$\mathrm{R}$ Core Team, 2021. R: A language and environment for statistical computing. R Foundation for Statistical Computing, Vienna, Austria.

Rawls, W.J., Pachepsky, Y.A., Ritchie, J.C., Sobecki, T.M., Bloodworth, H., 2003. Effect of soil organic carbon on soil water retention. Geoderma, 116, 61-76.

Rice, S.K., Collins, D., Anderson, A.M., 2001. Functional significance of variation in bryophyte canopy structure. American Journal of Botany, 88, 1568-1576.

Rice, S.K., Gagliardi, T.A., Krasa, R.A., 2018. Canopy structure affects temperature distributions and free convection in moss shoot systems. American Journal of Botany, 105, 1499-1511.

Rice, S.K., Schneider, N., 2004. Cushion size, surface roughness, and the control of water balance and carbon flux in the cushion moss Leucobryum glaucum (Leucobryaceae). American Journal of Botany, 91, 1164-1172.

Richardson, D.H.S., 1981. The Biology of Mosses. Blackwell Scientific Publications, Oxford.

Robinson, S.A., Wasley, J., Popp, M., Lovelock, C.E., 2000. Desiccation tolerance of three moss species from continental Antarctica. Australian Journal of Plant Physiology, 27, 379388.

Sayer, E.J., 2006. Using experimental manipulation to assess the roles of leaf litter in the functioning of forest ecosystems. Biological Reviews Cambridge Philosophical Society, 81, $1-31$.

Schindelin, J., Arganda-Carreras, I., Frise, E., Kaynig, V., Longair, M., Pietzsch, T., Preibisch, S., Rueden, C., Saalfeld, S., Schmid, B., Tinevez, J.Y., White, D.J., Hartenstein, V., Eliceiri, K., Tomancak, P., Cardona, A., 2012. Fiji: an open-source platform for biological-image analysis. Nature Methods, 9, 676-682.

Schneider, C.A., Rasband, W.S., Eliceiri, K.W., 2012. NIH Image to ImageJ: 25 years of image analysis. Nature Methods, 9, 671-675.

Schofield, W.B., 1981. Ecological significance of morphological characters in the moss gametophyte. The Bryologist, 84, 149-165.

Seitz, S., Nebel, M., Goebes, P., Käppeler, K., Schmidt, K., Shi, X., Song, Z., Webber, C.L., Weber, B., Scholten, T., 2017. Bryophyte-dominated biological soil crusts mitigate soil erosion in an early successional Chinese subtropical forest. Biogeosciences, 14, 5775-5788.

Senf, C., Buras, A., Zang, C.S., Rammig, A., Seidl, R., 2020. Excess forest mortality is consistently linked to drought across Europe. Nature Communications, 11, 6200. 
Simon, T., 1987. The leaf-area index of three moss species (Tortula ruralis, Ceratodon purpureus, and Hypnum cupressiforme). In: Pócs, T., Simon, T., Tuba, Z., Podani, J. (Eds.): IAB Conference of Bryoecology. Akadémiai Kiadó, Budapest-Vácrátót, Hungary, pp. 699-706.

Slatyer, R.O., 1967. Plant-Water Relationships. Academic Press, London, New York.

Söderström, L., Hagborg, A., von Konrat, M., BartholomewBegan, S., Bell, D., Briscoe, L., Brown, E., Cargill, D.C., Costa, D.P., Crandall-Stotler, B.J., Cooper, E.D., Dauphin, G., Engel, J.J., Feldberg, K., Glenny, D., Gradstein, S.R., He, X., Heinrichs, J., Hentschel, J., Ilkiu-Borges, A.L., Katagiri, T., Konstantinova, N.A., Larraín, J., Long, D.G., Nebel, M., Pócs, T., Puche, F., Reiner-Drehwald, E., Renner, M.A.M., Sass-Gyarmati, A., Schäfer-Verwimp, A., Moragues, J.G.S., Stotler, R.E., Sukkharak, P., Thiers, B.M., Uribe, J., Váňa, J., Villarreal, J.C., Wigginton, M., Zhang, L., Zhu, R.-L., 2016. World checklist of hornworts and liverworts. PhytoKeys, 59, 1-828.

Soudzilovskaia, N.A., van Bodegom, P.M., Cornelissen, J.H.C., 2013. Dominant bryophyte control over high-latitude soil temperature fluctuations predicted by heat transfer traits, field moisture regime and laws of thermal insulation. Functional Ecology, 27, 1442-1454.

Tucker, C.L., McHugh, T.A., Howell, A., Gill, R., Weber, B., Belnap, J., Grote, E., Reed, S.C., 2017. The concurrent use of novel soil surface microclimate measurements to evaluate
$\mathrm{CO} 2$ pulses in biocrusted interspaces in a cool desert ecosystem. Biogeochemistry, 135, 239-249.

Voortman, B.R., Bartholomeus, R.P., van Bodegom, P.M., Gooren, H., van der Zee, S.E.A.T.M., Witte, J.-P.M., 2014. Unsaturated hydraulic properties of xerophilous mosses: towards implementation of moss covered soils in hydrological models. Hydrological Processes, 28, 62516264.

Wang, Z., Bader, M.Y., 2018. Associations between shoot-level water relations and photosynthetic responses to water and light in 12 moss species. AoB PLANTS, 10.

Weber, B., Berkemeier, T., Ruckteschler, N., Caesar, J., Heintz, H., Ritter, H., Braß, H., Freckleton, R., 2016. Development and calibration of a novel sensor to quantify the water content of surface soils and biological soil crusts. Methods in Ecology and Evolution, 7, 14-22.

Zotz, G., Büde, B., Meyer, A., Zellner, H., Lange, O.L., 1997. Water relations and $\mathrm{CO}_{2}$ exchange of tropical bryophytes in a Lower Montane Rain Forest in Panama. Botanica Acta, $110,9-17$.

Zotz, G., Schweikert, A., Jetz, W., Westerman, H., 2000. Water relations and carbon gain are closely related to cushion size in the moss Grimmia pulvinata. New Phytologist, 148, $59-67$.
Received 31 March 2021

Accepted 9 June 2021

\section{SUPPORTING INFORMATION}

Table S1. Equations of calibration curves for studied soil substrates and moss species. The fit quality is assessed by the root mean square error (RMSE) and the determination coefficient $\left(\mathrm{R}^{2}\right)$ between measured and modeled water content.

\begin{tabular}{|c|c|c|c|c|c|c|c|c|}
\hline Sample & Calibration equation & $\mathrm{a}$ & $\mathrm{b}$ & $\mathrm{c}$ & $\mathrm{d}$ & $\mathrm{e}$ & RMSE & $\mathrm{R}^{2}$ \\
\hline $\begin{array}{l}\text { Angulatensandstein- } \\
\text { Formation }\end{array}$ & $y=\exp (a \cdot x) \cdot b \cdot x+c$ & 0.0043 & $9.125 \mathrm{e}^{-07}$ & 0.264 & & & 0.027 & 0.928 \\
\hline Löwenstein-Formation & $\begin{array}{l}y=a \cdot x+b(B W P<1250 m V) \\
y=a \cdot x+b(B W P>1250 m V)\end{array}$ & $\begin{array}{l}0.00018 \\
0.00215 \\
\end{array}$ & $\begin{array}{l}0.0322 \\
-2.437 \\
\end{array}$ & & & & $\begin{array}{l}0.002 \\
0.016 \\
\end{array}$ & $\begin{array}{l}0.990 \\
0.954\end{array}$ \\
\hline Psilonotenton-Formation & $y=\exp (a \cdot x) \cdot b \cdot x+c$ & 0.0038 & $2.055 \mathrm{e}^{-06}$ & 0.221 & & & 0.031 & 0.926 \\
\hline Trossingen-Formation & $y=\exp (a \cdot x) \cdot b \cdot x+c$ & 0.0065 & $3.218 \mathrm{e}^{-08}$ & 0.238 & & & 0.010 & 0.990 \\
\hline $\begin{array}{l}\text { Aamblystegium serpens } \\
\text { (Lab) }\end{array}$ & $y=(a+b \cdot x)$ & -2.555 & 0.0045 & & & & 0.703 & 0.979 \\
\hline Brachythecium rutabulum & $y=a \cdot x+b$ & 0.0096 & -0.401 & & & & 0.229 & 0.996 \\
\hline Eurhynchium striatum & $y=a \cdot x+b$ & 0.0194 & -0.617 & & & & 0.205 & 0.995 \\
\hline Oxyrrhynchium hians & $y=a \cdot x+b$ & 0.0127 & -0.414 & & & & 0.200 & 0.993 \\
\hline Oxyrrhynchium hians (Lab) & $y=\exp (a \cdot x) \cdot b \cdot x+c$ & 0.0008 & 0.0036 & -0.057 & & & 0.133 & 0.998 \\
\hline Plagiomnium undulatum & $y=a \cdot x^{4}+b \cdot x^{3}+c \cdot x^{2}+d \cdot x+e$ & $-3.141 \mathrm{e}^{-11}$ & $7.996 \mathrm{e}^{-08}$ & $-6.066 \mathrm{e}^{-05}$ & 0.0198 & -0.5402 & 0.223 & 0.994 \\
\hline
\end{tabular}



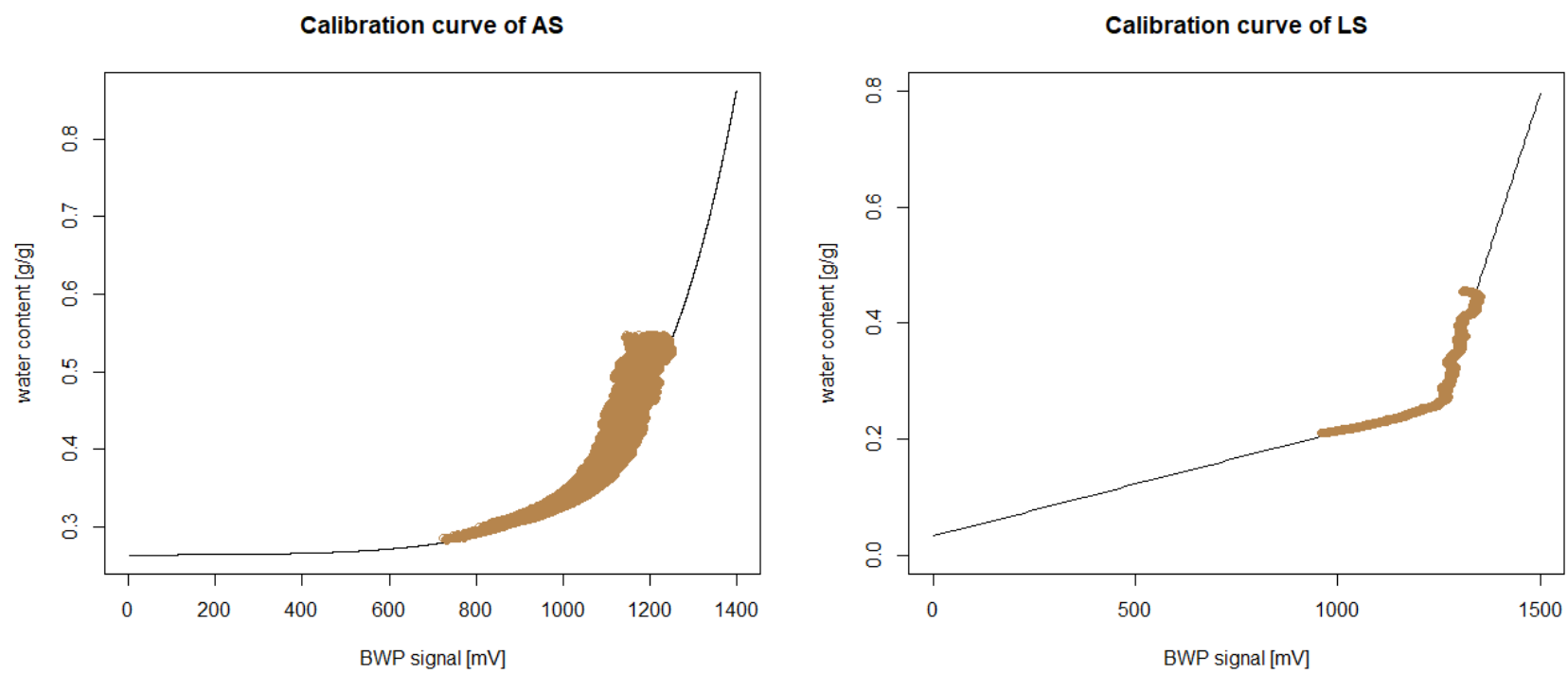

Calibration curve of PT

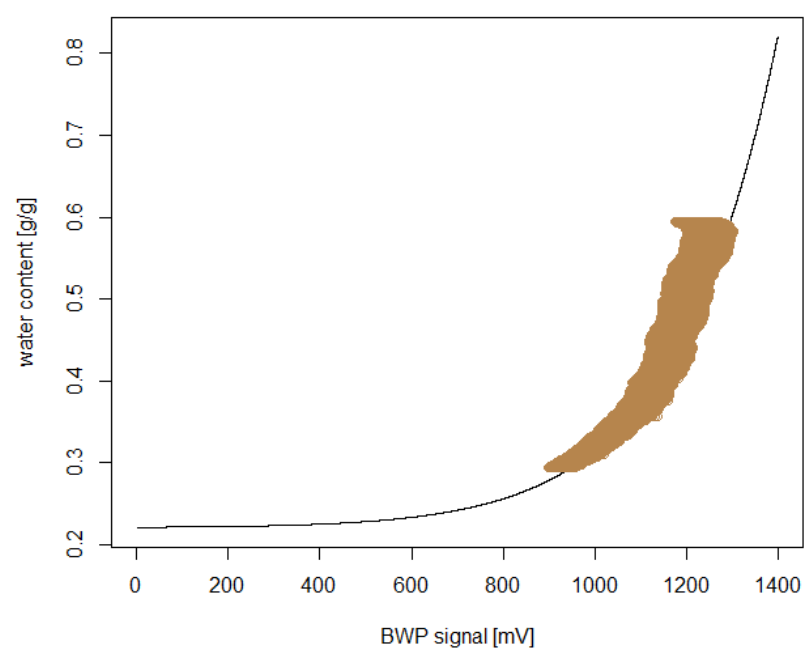

Calibration curve of TS

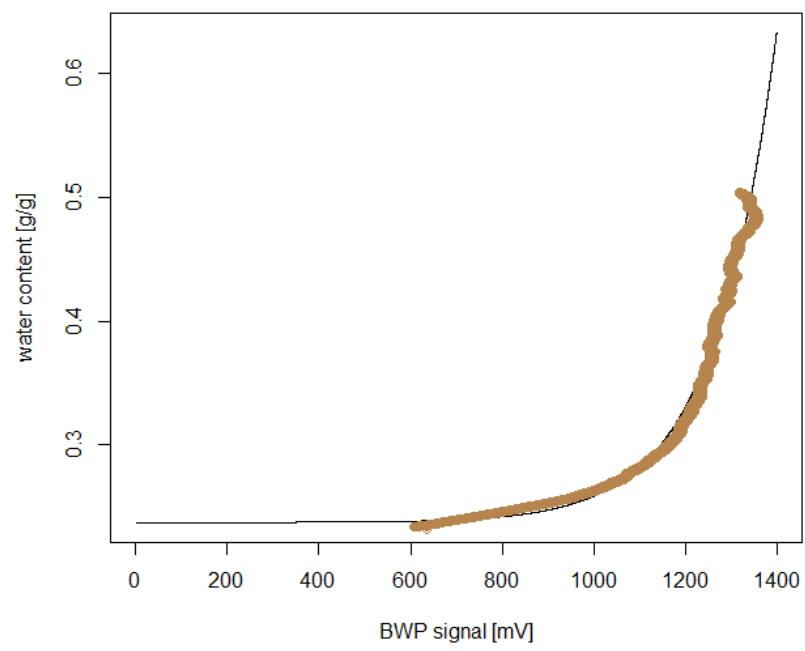

Calibration curve of A. serpens (Lab)

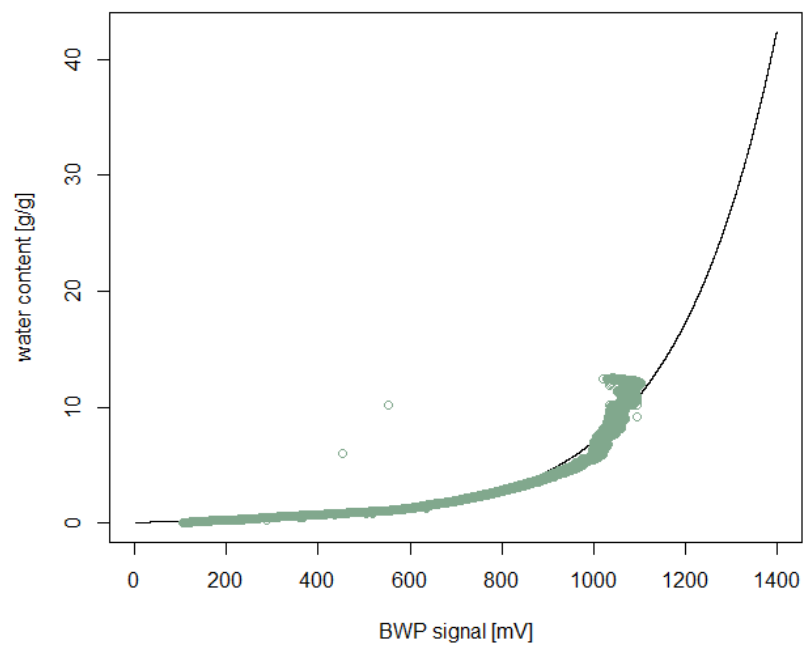

Calibration curve of B. rutabulum

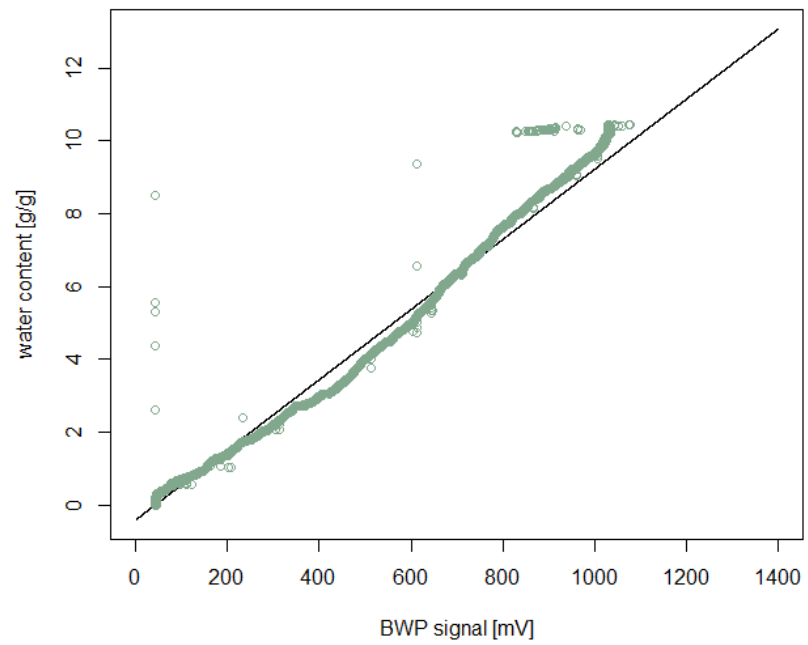


Calibration curve of E. striatum

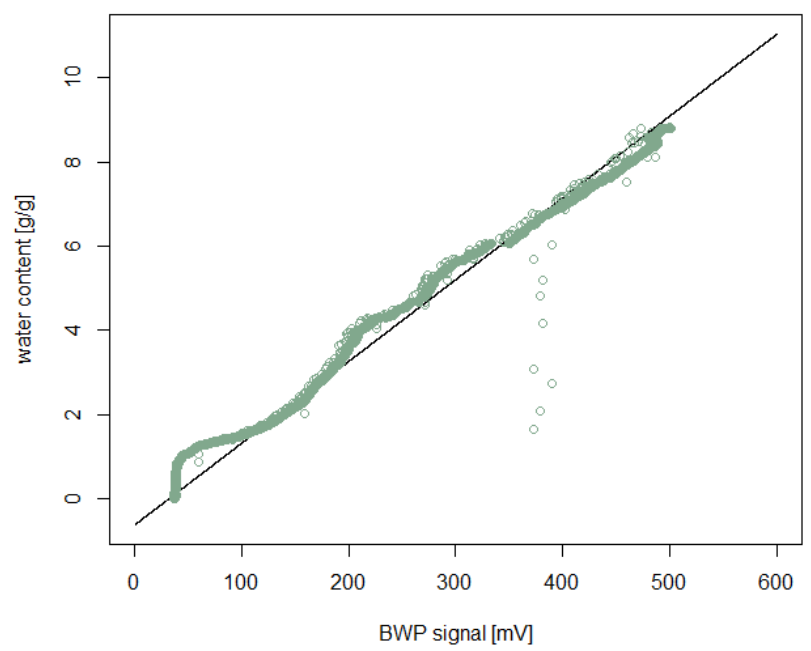

Calibration curve of $\mathrm{O}$. hians (Lab)

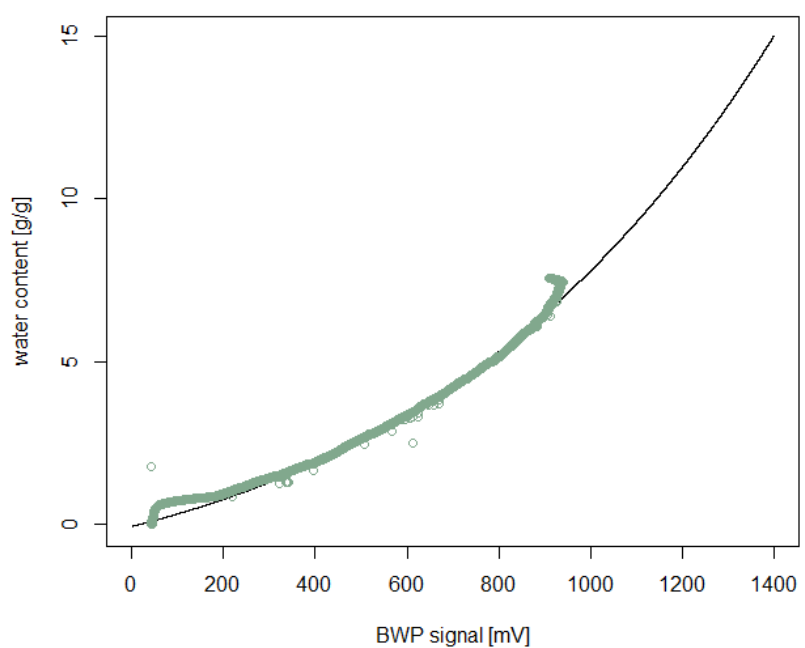

Calibration curve of $O$. hians

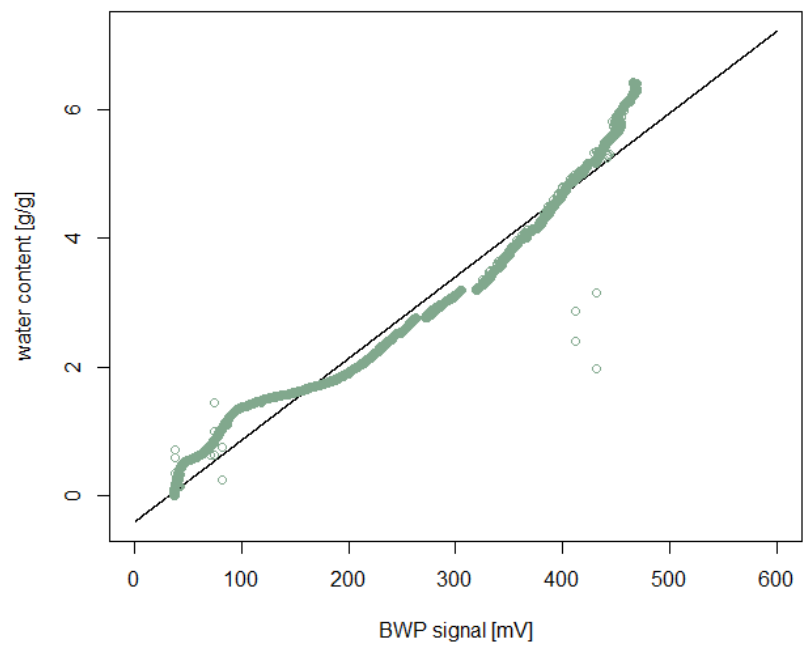

Calibration curve of $\mathrm{P}$. undulatum

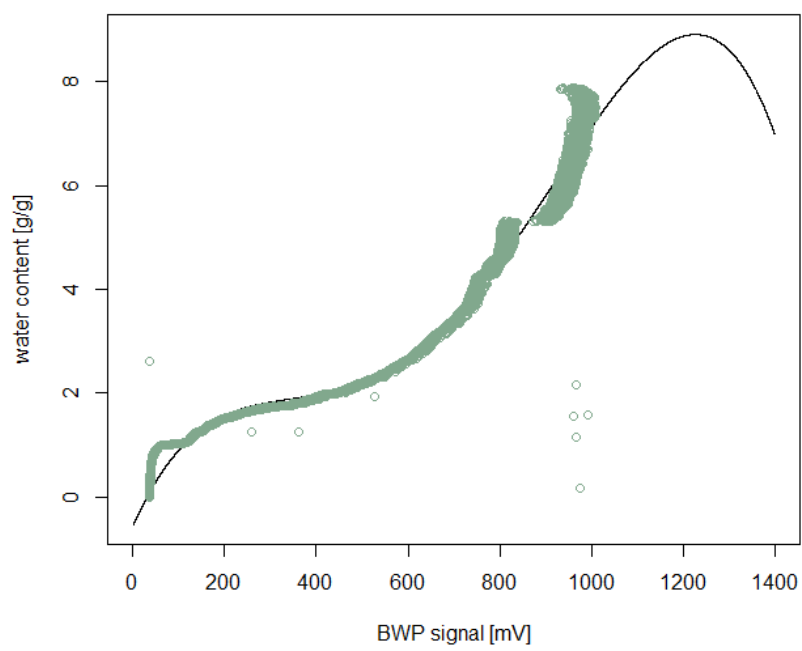

Figs. S1-S10. Plots of calibration curves for studied soil substrates and moss species. Measured water contents for soil substrates are illustrated in brown and for moss species in green.

Table S2. Maximum water storage capacity values $\left(\mathrm{WSC}_{\max }\right)$ and sample sizes of the studied moss species for immersion and spray technique as gravimetric $\mathrm{WSC}_{\max }\left(\mathrm{g} \mathrm{g}^{-1}\right)$, percentage $\mathrm{WSC}_{\max }(\%)$ and $\mathrm{WSC}_{\max }$ per unit area $(\mathrm{mm}), \pm$ standard error of the mean.

\begin{tabular}{|l|l|l|l|l|l|l|l|}
\hline Moss species & $\begin{array}{l}\text { Sample } \\
\text { size }\end{array}$ & $\begin{array}{l}\mathrm{WSC}_{\max } \\
\text { immersion }\left(\mathrm{g} \mathrm{g}^{-1}\right)\end{array}$ & $\begin{array}{l}\mathrm{WSC}_{\max } \\
\text { spray }\left(\mathrm{g} \mathrm{g}^{-1}\right)\end{array}$ & $\begin{array}{l}\mathrm{WSC}_{\max } \\
\mathrm{immersion}(\%)\end{array}$ & $\begin{array}{l}\mathrm{WSC}_{\max } \\
\text { spray (\%) }\end{array}$ & $\begin{array}{l}\mathrm{WSC}_{\max } \\
\text { immersion }(\mathrm{mm})\end{array}$ & $\begin{array}{l}\mathrm{WSC}_{\max } \\
\text { spray }(\mathrm{mm})\end{array}$ \\
\hline $\begin{array}{l}\text { Amblystegium } \\
\text { serpens }(\mathrm{Lab})\end{array}$ & 8 & $14.097 \pm 1.28$ & $10.082 \pm 1.25$ & $1409.668 \pm 127.82$ & $1008.176 \pm 125.09$ & $4.947 \pm 0.74$ & $3.144 \pm 0.23$ \\
\hline $\begin{array}{l}\text { Brachythecium } \\
\text { rutabulum }\end{array}$ & 8 & $11.800 \pm 0.81$ & $10.049 \pm 0.66$ & $1179.965 \pm 80.52$ & $1004.919 \pm 65.74$ & $3.152 \pm 0.31$ & $2.712 \pm 0.25$ \\
\hline $\begin{array}{l}\text { Eurhynchium } \\
\text { striatum }\end{array}$ & 17 & $11.223 \pm 0.62$ & $9.629 \pm 0.40$ & $1122.260 \pm 61.55$ & $962.943 \pm 39.78$ & $3.342 \pm 0.21$ & $2.820 \pm 0.18$ \\
\hline $\begin{array}{l}\text { Oxyrrhynchium } \\
\text { hians }\end{array}$ & 7 & $9.686 \pm 1.41$ & $7.880 \pm 0.57$ & $968.598 \pm 141.08$ & $787.973 \pm 56.90$ & $2.094 \pm 0.12$ & $1.945 \pm 0.09$ \\
\hline $\begin{array}{l}\text { Oxyrrhynchium } \\
\text { hians (Lab) }\end{array}$ & 7 & $9.934 \pm 1.24$ & $11.038 \pm 1.23$ & $993.381 \pm 123.82$ & $1103.796 \pm 122.86$ & $2.703 \pm 0.32$ & $2.448 \pm 0.21$ \\
\hline $\begin{array}{l}\text { Plagiomnium } \\
\text { undulatum }\end{array}$ & 8 & $7.308 \pm 0.80$ & $8.146 \pm 0.32$ & $730.792 \pm 79.89$ & $814.613 \pm 31.58$ & $1.841 \pm 0.29$ & $1.870 \pm 0.13$ \\
\hline
\end{tabular}

